\title{
SIMMER II Analysis of the CAMEL II C6 and C7 Experiments (Simulated Fuel Penetration into a Primary Control Assembly)
}

\author{
G. P. DeVault
}

\section{DiSCLAIMER}

\begin{abstract}
This report was prepared as an account of work sponsored by an agency of the United States Government. Neither the United States Government nor any agency thereof, nor any of their employees, makes any warranty, express or implied, o! assunes any legal liability or responsibility for the accuracy, completeness, or usefulness of any information, apparatus, product, or process disclesed, or represents that its use would not infringe privately owned rights. Reference herein to any specific commercial product, process, or service by trade name, trudemerk, manufacturer, or otherwise does not necessarily constitute or imply its endorsement, recommendation, or lavoring by the United States Government or uny agency thereof. The views and opinions of authors expressed herein dn not necessarily state or $r$ illect thrse of the United States Goverament or any agency thereof.
\end{abstract}
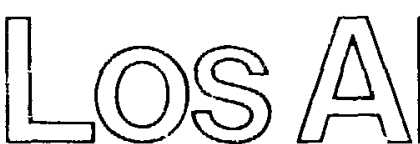


\section{CONTENTS}

FiguRE $5 \ldots \ldots \ldots \ldots \ldots \ldots \ldots \ldots \ldots \ldots \ldots \ldots \ldots \ldots \ldots \ldots \ldots \ldots \ldots \ldots \ldots \ldots \ldots$

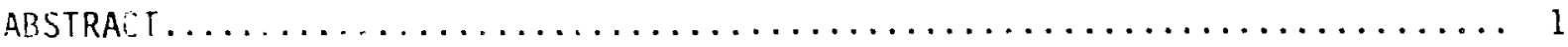

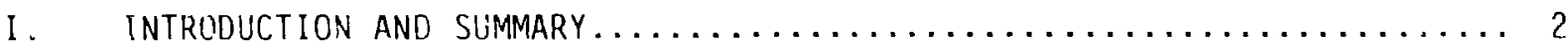

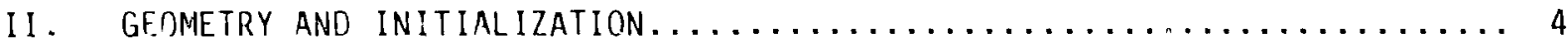

$\therefore$ General Characteristics of the CAMEL II Loop and Test Sections..... 4

B. Geonetric Arrangeilient and SIMMER-II Mesh................ 6

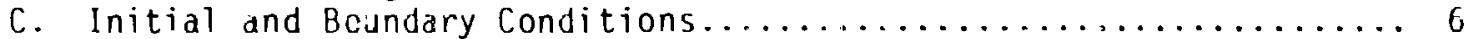

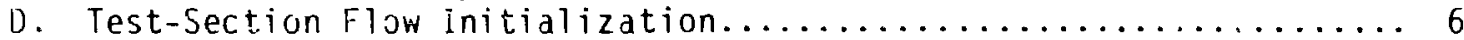

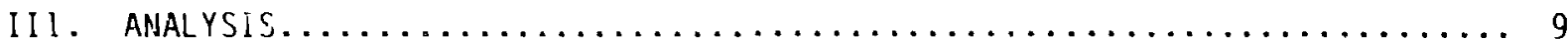

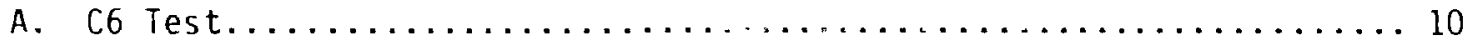

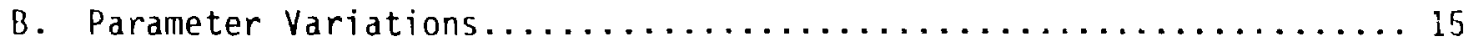

IV. COMPARISONS WITH CAMEL II C6 AND $C 7$ EXPERIMENTS $\ldots \ldots \ldots \ldots \ldots \ldots \ldots \ldots \ldots$

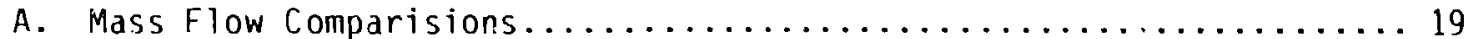

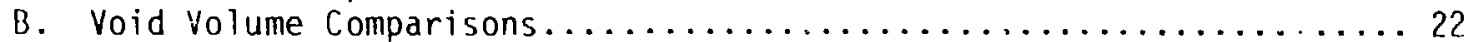

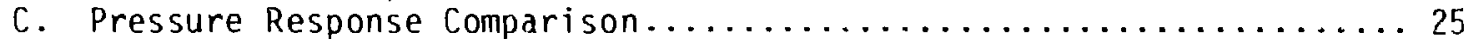

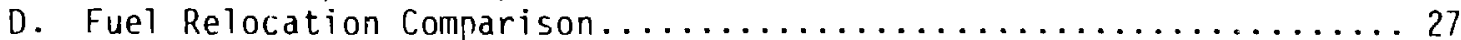

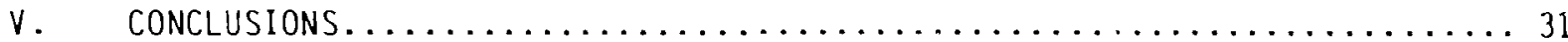

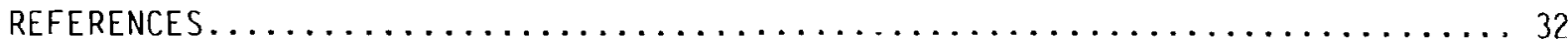


FIGURES

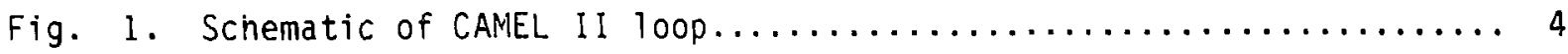

Fig. 2. $C 6$ and $C 7$ test sections................................ 5

Fig. 3. Geometric representation of the SIMMER-II calculational mesh...... 7

Fig. 4. Time histories of the $\mathrm{C} 6$ and $\mathrm{C} 7$ fuel driver pressures........... 9

Fig. 5. Various variables at selected times for C6 calculation (Case 1)... 11

Fig. 6. Time histories of selected var,ables for C6 calculation (Case 1)...13

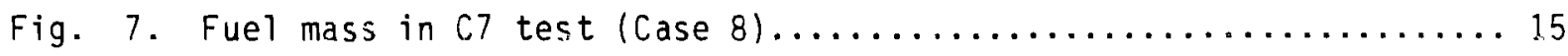

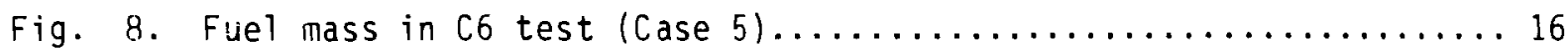

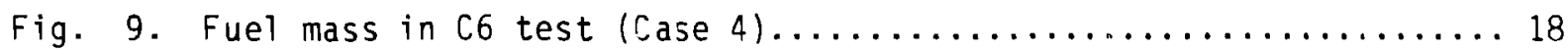

Fig. 10. Total mass flow rates in 66 test (Case i)...................... 19

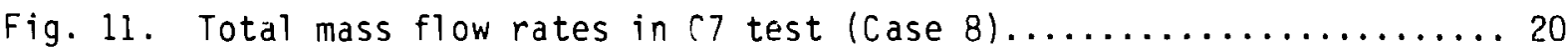

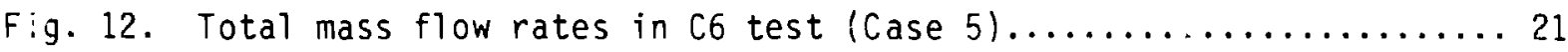

Fig. 13. Motion of the liquid-void interface for axial cells

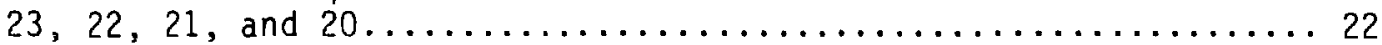

Fig. 14. Sodium void volume history, c6 test...................... 24

Fig. 15. Sodium void volume history, $C 7$ test........................ 24

Fig. 16. Inlet interface position for $C 6$ and $C 7$ tests................. 25

Fig. 17. Experimental pressure (PTK-2) and inlet flow (FM-3), C6 test..... 26

Fig. 18. SIMMER-II pressure and flow $11 \mathrm{~cm}$ below injection point,

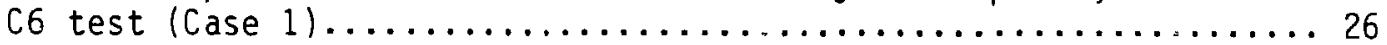

Fig. 19. Time history of selected variables for C6 test (Case 1)......... 28

Fig. 20. Time history of selected variables for C6 test (Case 5).........29

Fig. 21. Time history of selected variables for 67 test (Case 8$) \ldots \ldots \ldots . .30$ 
SIMMER-II ANALYSIS OF THE CAMEL II CE AND C7 EXPERIMENTS (SIMULATED FUEL PENETRATION INTO A PRIMARY CONTROL ASSEMBLY)

by

G. P. DeVault

ABSTRACT

The CAMEL C6 and $C 7$ tests, performed at Argonne National Laboratory, simulated asymetric midplane fuel injection into a $\mathrm{n}$. voided fully withdrawn primary control assembly during t.e meltdown phase of a hypothetical coredisruptive accident in a liquid-metal-cooled fast breeder reactor. These tesis were modeled with no a priori knowledge of the experimental results using the SIMMER-II code. Subsequent comparison of caliulations with experimental results showed good agreement. 


\section{INTRODUCTION AND SUMMARY}

During hypothetical core-disruptive accidents (HCDAs) in liquidmetal-cooled fast breeder reactors (LMFBRs), fuel removal from the active core region is important. Calculations 1 of the meltdown phase of such accidents ${ }^{2,3}$ have shown that fuel slumping and recompaction can lead to recriticalities and significant energetics. The number and severity of such energetic events are related directly to the availability of mobile fuel in tre active core.

Early fuel losses from the active core region can eliminate or moderate recriticalities. Prior analyses of possible fuel escape paths have included fluw to the axial blankets and penetration into the gaps between blanket subassemblies. A recent SIMMER-II (Ref. 4) calculation showed that the primary control assembly ( $P C A)$ may provide an excellent fuel escape path from the active core region of an LMFBR.

Even more recently, experiments were performed and analyzed ${ }^{5}$ at. Argonne National Laboratory (ANL) to simulate midplane fuel injection into a nonvoided fully withdrawn PCA containing stagnant sodium during the meltdown phase of an HCDA in an LMFBR. Their test section, mounted in the CAMEL II sodium-f1ow loop, (Components and Materials Evaluation Loop) at ANL, was designed to match both stead:-state and transient hydraulic behavior of a PCA. It contained a 1arge, open inlet pipe that simulated the fully-withdrawn PCA region. Above this was a transition to a narrower exit pipe that simulated the absorber pin-bundle and bypass region. In the side wall just below the transition was a $2.54 \mathrm{~cm}$ diameter fuel-injection pert. Molten fuel from a thermite reaction at $3470 \mathrm{~K}$ was driven into the test section with compressed argon gas. The sodium in the test section was at $773 \mathrm{~K}$. To determine the subsequent fluid dynamics ariu fue? relocation, measurements relating to flow, pressure, and void fraction were made along the test section. Two tests were performed: in C6, the fuel was injected with an initial argon driver pressure of $0.63 \mathrm{MPa}$; in $\mathrm{C7}$, the driver pressure was $0.31 \mathrm{MPa}$.

The SIMMER-II calculations and analyses of the $\mathrm{C} 6$ and $\mathrm{C} 7$ tests were performed concurrently with these experiments. These calculations and the preliminary analysis were done with no a priori knowledge of the experimental results, although it was known that about half of the injector iuel iriventory of $4 \mathrm{~kg}$ was injected. The only information furnished by ANL were those necessary to set up the SIMMER-II calculations. This included (a) the geometries of the test section, CAMEL II loop, and injector system; (b) the fuel and coolant 
temperatures at the injection time; (c) the steady-state pressure drops; (d) the pressure history of the argon driver gas in the thermite injector; and (e) the s ieady-state and initial transient flows.

Typically, the calculations showed fuel flowing from the fuel-injector tank, descending through the injector tube, and melting through the diapriagm at the point of injection into the test saction. There was then a fuel/coulant interaction (FCI) that reversed the flow of the fuel in the injector tube and sloshed molten fuel to the upper part of the fuel-injector tank. A little less than half the fuel inventory froze as a crust on the tank walls. Then the remaining fuel was driven back through the injector tube to the test section. Because the original FCI had caused voiding in the test section near the injection doint, fuel was relatively free ti enter the test section.

The SIMMER-il calculations were made in cylindrical coordinates with azimuthal symmeiry. The experiments, however, did not have this symmetry because of the injector. Thus, a comparison of the fine details of the exporimenta? and calculated results is not generally appropriate. However, comparisons of the overall results showed that, in most instances, SIMMER-II did a remarkable job. The comparisons showed that the SIMMER-II calculations were reasonable for (a) predicting the amourit of fuel injected into the test section, (b) tracking the liquid/void interfaces both up and down the test section, (c) predicting the test-section total mass flows at any time during the injection, and (d) explaining the qualitative behavior of the FCIs.

The SIMMER-II results also offered a possible alternative explanation for an exprimental observation. After the experiments, considerable fuel was frozen as a crust on the walls of the fuel-injector tank. Although this crust was originaliy thought to have resulted from the energetic thermite reaction, the calculations suggested that it may have been the initial FCI that reversed the injector flow back into the tank where much of the fuel froze on the walls. 


\section{GEOMETRY AND INITIALIZATICN}

For this study the ANL CAMEL II loop and the C6 and C7 test sections were modeled with SIMMER-II. The CAMEL II loop is a sodium loop capable of temperatures to $810 \mathrm{~K}$ and mass flow rates of more than $5 \mathrm{~kg} / \mathrm{s}$; it was designed to allow hydraulic modeling of LMFBR subassemblies for simulated fuel-melting tests. The $C 6$ and $C T$ test sections were designed to simulate midplane fuel injection into a nonvoided, fully withdrawn PCA during the transition phase of an HDA.

\section{A. General Characteristics of the CAMEL II Loop and Test Sections}

A schematic of the CAMEL II loop flow paths and hydraulic parameters is shown in Fig. 1. This loop allows easy replacement of the test sections between the upper and lower plena. The inlet valve just above the lower plenum is used to simulate the subassembly inlet orificing.

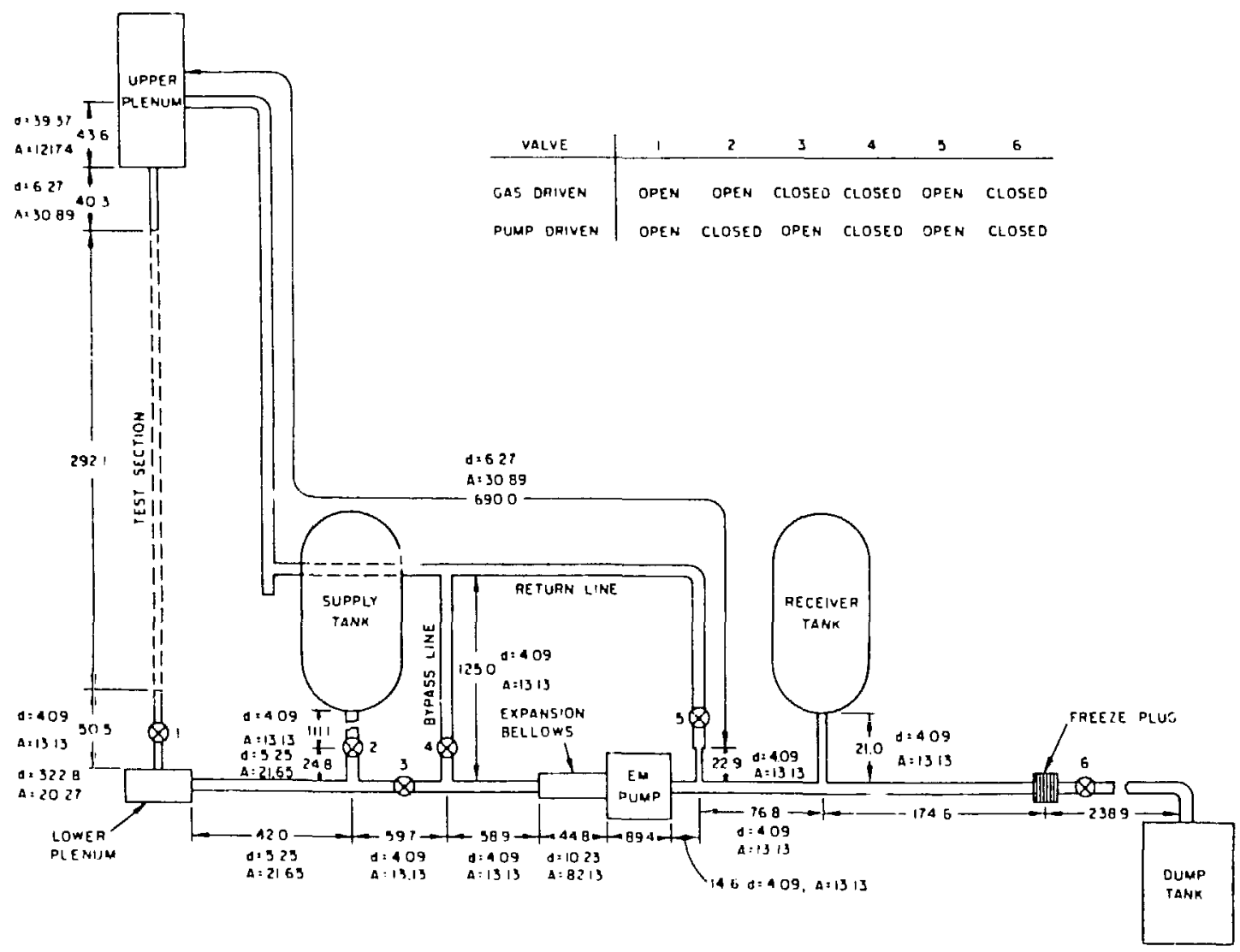

Fig. 1 .

Schematic of CAMEL II loop

(dimensional units $\mathrm{cm}$ ). 
The test section design is shown in Fig. 2. The midplane fuel-injection level lies below the reduced-flow area (which models the withdrawn absorber pin bundle). The large open area below the injection point represents the structureless region from which the absorber pin bundle was withdrawn in the primary control subassembly.

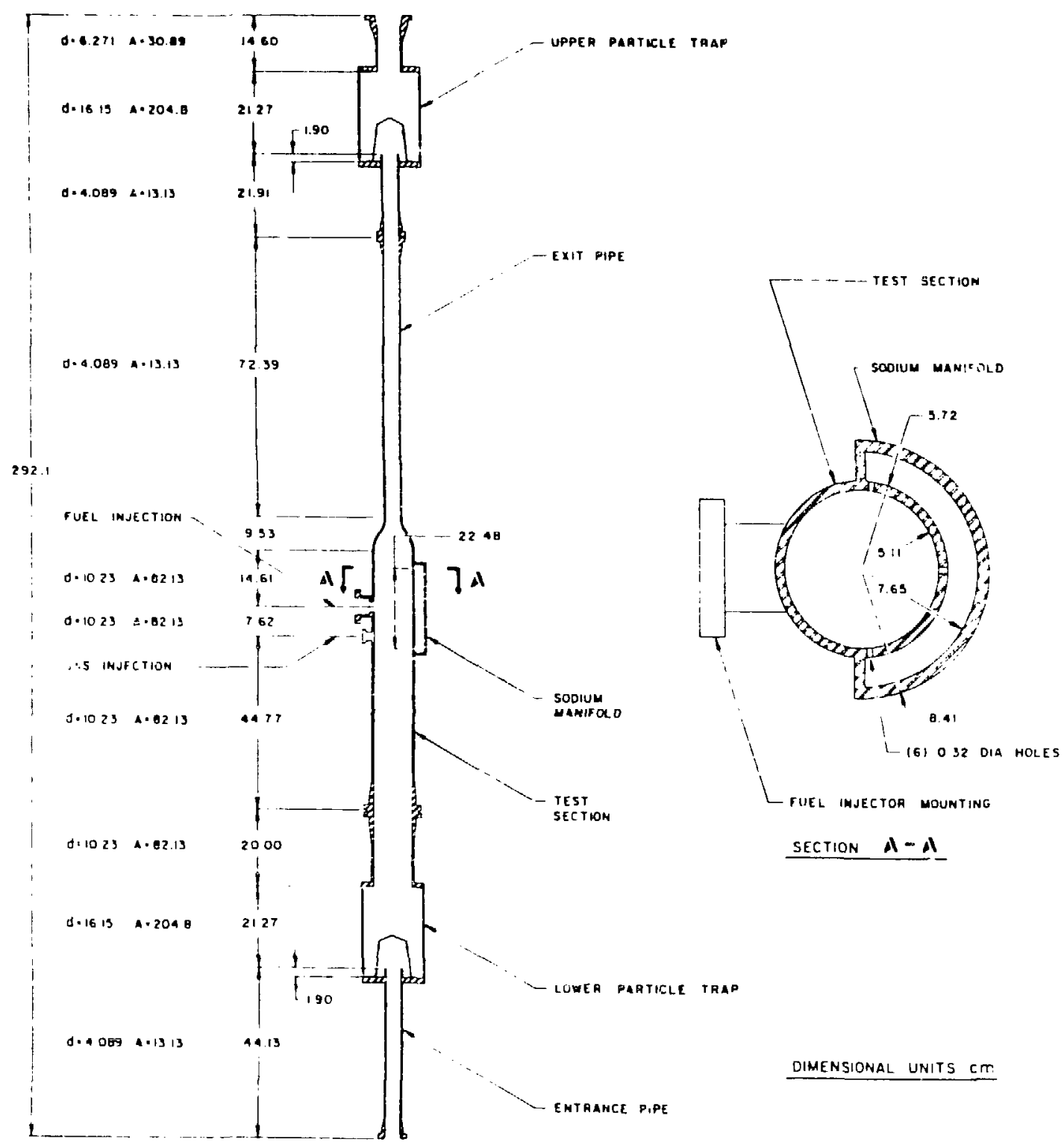

Fig. 2.

C6 and 0.7 test sections. 
The SIMMER-II cylindrical geometry used for these calculations is shown in Fig. 3. SIMMER-II is a two-dimensional code; when used in cylindrical geometry it is restricted to $r-z$ coordinates with azimuthal symmetry. The $C 6$ and $C 7$ tests were three-dimensional by virtue of the fuel-injector system. To simulate the experiments with SIMMER-II, the injector must azimuthally surround the ter,t section. However, the asymmetry of the real injector could be partially compensated for by applying the proper flow areas, surface areas, and hydraulic diameters $0_{i}$ the injector $i_{i l}$ the SIMMER-II calculations. The simulated test section had exactly the dimensions of the experimental test section. In addition, the axial cells above and below the test section were chosen to have lengths and diameters representative of the piping in the CAMEL II loop; that is, the pressure drops in these sections should, for a given flow, be the same as in the corresponding parts of the CAMEL II loop. The azimuthally symmetric injector used in the SIMMER-II simulation is shown in Fig. 3 , with the fuel injector initially in the bottom (blackened region) of the fuel-injector tank. The crosshatched and shaded regions represent rigid structure and test-secition wa11s.

The calculationul mesh had 6 radial cells $(I=1, \ldots, 5)$ and 48 axial cells $(J=1, \ldots, 48)$. A given mesh cell is referred to by $(I, J)$. The fuel-injection ring was in $(2,23)$ with the fuel tank occupying $(5,26-34)$. The injector piping was given a hydraulic diameter that matched that of the actual piping from the fuel tank to the injection point. In the outer ring, $I=6$, was a gas-filled tank that transmitted the applied driving pressure $P(t)$ to the fusl-injector tank.

C. Initial aidd Boundary Conditions

To match the $\mathrm{C6}$ and $\mathrm{C} 7$ experiments, the initial sodium and wall temperatures were assumed to be $773 \mathrm{~K}$. In addition, normal-operation top and bottom pressure boundary conditions of 0.076 and $0.950 \mathrm{MPa}$, respectively, were specified. These boundary conditions were used to establish proper normaloperation fluid dynamir. flow. The pressure boundary conditions were then modified, as will be described, to be consistent with transient HCDA conditions.

D. Test-Section Flow Initialization

Before allowing the test section to interact with the hot fuel in the injector by diaphragm failure, a steady-state calculation was performed with SIMMER-II to ensure that proper fluid-dynamic characteristics were satisfied. That is, in normal operation, about $90 \%$ of the test section pressure drop should 6 


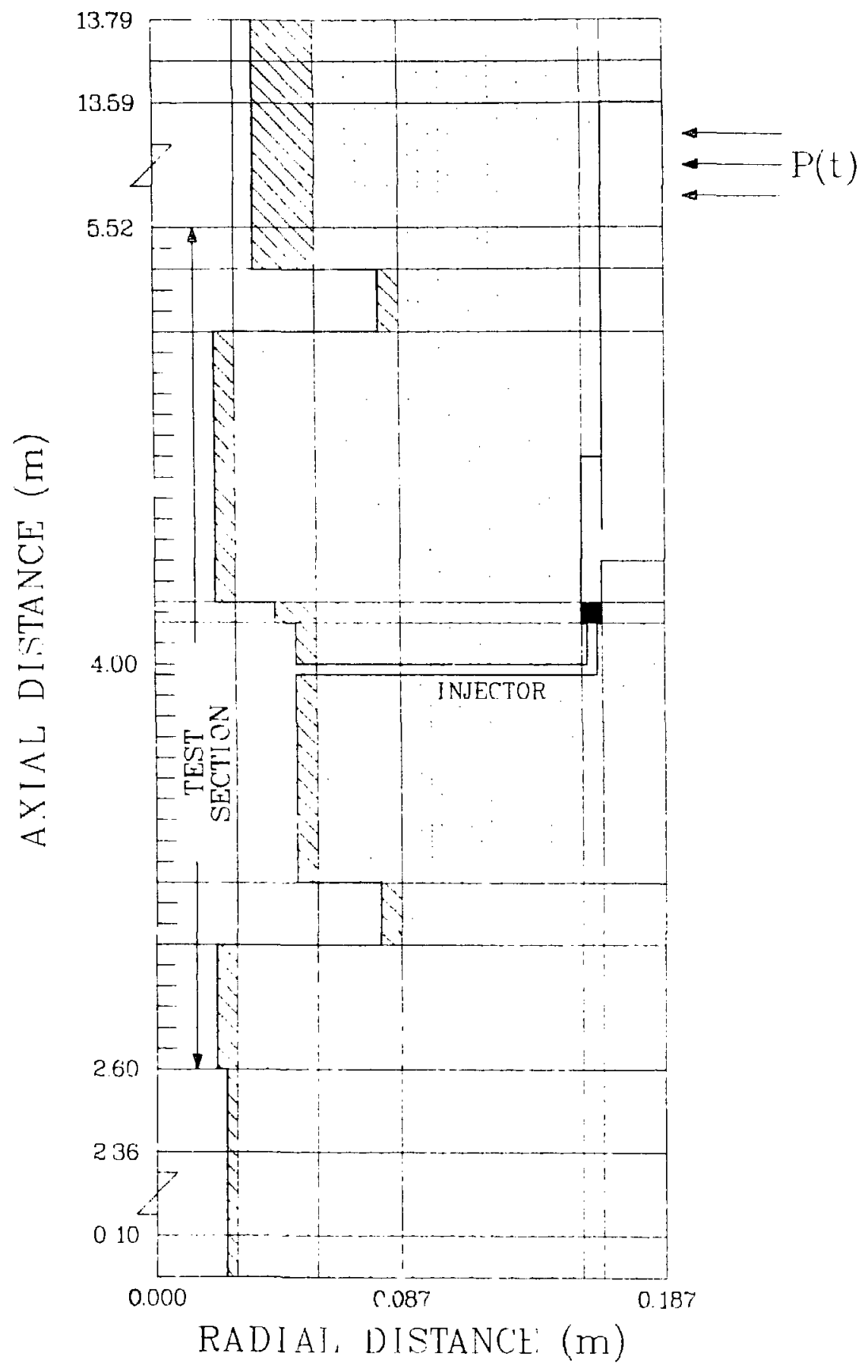

Fig. 3.

Geometric representation of the SIMMER-II calculational mesh. 
be across the inlet orifice plates; the average fluid velocity near the injector should be $71 \mathrm{~cm} / \mathrm{s}$. The relevant SIMMER-II steady-state hydraulic parameters are given in Table I. Of these, the first three were forced by design to be identical with the experimental values. That is, the SIMMER-II mesh geometry for the test scation agreed with the $C 6$ and $C 7$ tests, and with an imposed normal steady-state pressure drop of $0.83 \mathrm{MPa}$ over the test section (including the orifice in the bottom of $\mathrm{J}=3$ ), the orifice coefficient was adjusted to give a $71-\mathrm{cm} / \mathrm{s}$ flow velocity in the injector portion of the test section. In Table I the resulting pressure drops on the inlet and exit sides of the injection point and the sodium mass flow rate are also compared with an actual PCA and the C6 and $C 7$ tests. The reason that the calculated mass flow rate is smaller than the experimental value is that, even for single-phase flow, the SIMMER-II code requires a nonzero vapor volume with its 1 iquid -- in this case $5 \%$.

Next, this problem was continued with the lower soundary pressure reduced to that of the top boundary plus a gravity head. This modeled the HCDA flow coastdown for the control subassembly. The results of this calculation were then used to form input for the transient injection calculations. For the transient calculations, the fuel tank contained $4.2 \mathrm{~kg}$ of molten $\mathrm{UO}_{2}$ at $3470 \mathrm{~K}$. The applied driving pressure $P(t)$ was transmitted to the fuel by $\mathrm{N}_{2}$ cover gas. The injection pipe was evacuated, and there was a thin diaphragm at the injection point. Thus a transient caiculation consisted of initiating the driver pressure at $t=0$ and forcing molten fuel down through the injector pipe to the diaphragm. The diaphragm failed by melting, typically at $20 \mathrm{~ms}$, allowing the fuel to mix and interact with the sodium conlant in the test section.

TABLE I

STEADY-STATE HYDRAULIC PARAMETERS

\begin{tabular}{|c|c|c|c|}
\hline & $\underline{P C A}$ & $\mathrm{C} 6$ and $\mathrm{C7}$ Tests & SIMMER - I I \\
\hline$d_{h}, c m$ & 11.02 & 10.23 & 10.23 \\
\hline Area, $\mathrm{cm}^{2}$ & 105.00 & 82.13 & 82.13 \\
\hline Velocity, cm/s & 71.0 & 71.00 & 71.00 \\
\hline Inlet $\Delta \mathrm{P}, \mathrm{MPa}$ & 0.709 & 0.749 & 0.774 \\
\hline Exit $\Delta \mathrm{P}, \mathrm{MPa}$ & 0.054 & 0.085 & 0.053 \\
\hline$\dot{\mathrm{m}}, \mathrm{kg} / \mathrm{s}$ & 6.21 & 4.85 & 4.60 (5\% vapor) \\
\hline
\end{tabular}




\section{ANALYSIS}

Two basic calculations were performed with SIMMER-II. They corresponded directly to the $C 6$ and $C 7$ experiments and differed from each othe in the driving-pressure time evolution and in the coolant velocity at the injection time. In addition, the sensitivity of the basic $C 6$ calculation to certain parameter variations was investigated.

In the $\mathrm{C} 6$ test, fuel was injected at a driving overpressure of $0.59 \mathrm{MPa}$ into coolant flowing at $4.7 \mathrm{~cm} / \mathrm{s}$; in the $\mathrm{C7}$ tost, fuel was injected at a diving overpressure of $0.31 \mathrm{MPa}$ into coclant flowing at $-1.3 \mathrm{~cm} / \mathrm{s}$. These pressures were relative to the normal pressure of $0.16 \mathrm{MPa}$ at the injection point of the test section. The driving pressures vs time for these two tests are shown in Fig. 4 .

We discuss the time evolution of the $C \sigma$ test calculation in some detail because its main features are typical of the caiculated cases.
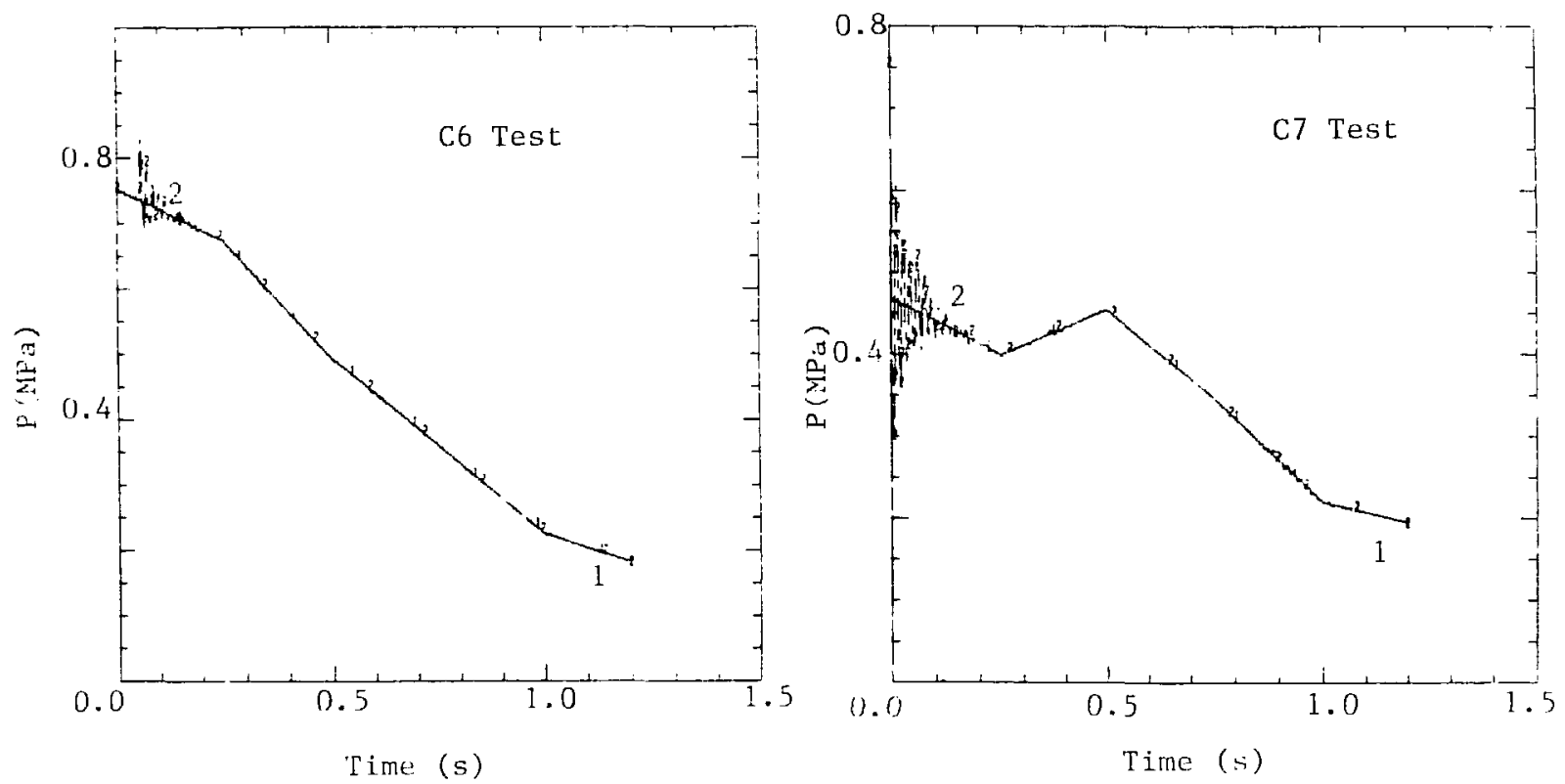

Fig. 4.

Time histories of lite $C 5$ and $C 7$ fuel driver pressures

$(1=P(t) ; 2$ = pressure trarismitted to fuel tank). 
At $t=0.0 \mathrm{~s}$, the $3470-k$ fuel was in the bottom of the fuel-injector tank (Fig. 5a). The driving pressure (Fig. 5b) and gravity caused it to flow down through the evacuated injector tube to the steel diaphragm at the entrance to the test section. The diaphragm failed by melting at $t=0.022 \mathrm{~s}$. Figures $5 \mathrm{c}$ and 5 d show that by $0.045 \mathrm{~s}$, fue? nad entered the test section and mixed with the sodium and and the resulting FCI locally pressurized the test section. For the next $0.5 \mathrm{~s}$, this pressirization inhibited addicional fuel $f$.om entering the test section; rather, fuel was returned through the injector pipe and sloshed high up in the injector tank, where much of it froze on the tank walls. Some of the injected fuel formed particles and some of it formed ciust on the tesi siction walls. Figures $5 \mathrm{e}$ anj $5 \mathrm{f}$ show the situation at $0.50 \mathrm{~s}$. Most of the remaining liquid fuel was in the fuel injector tank. The FCI pressure spike had been relieved; the driving pressure once again became dominant, and liquid fuel was again injected into the test section. However, as Fig. $5 g$ indicates, the test-section coolant had been voided near the iijector. Thus further fuel injection did not result in FCIs at the injection point, and all the remaining liquid fuel was injected. The final fuel distribution at $1.20 \mathrm{~s}$ is given in Fig. Sh; about half the initial fuel inventory was injected.

Time iistories with more quantitative results of the preceding discussion are given in Fig. 6. Figure $6 \mathrm{a}$ shows that, of the initial $4.20 \mathrm{~kg}$ fuel inventory, a little over half $(2.27 \mathrm{~kg})$ was injected into the test section in two phases. Figures $6 b, 6 c$, arid $6 d$ illustrate fuel draining out of the lower portion of the fuel-injector tank, through the injector pipe, and into the test section, where the resulting FCI created a pressure pulse of $9.0 \mathrm{MPa}$. This pressure then forced the remaining fuel back through the injector pipe (Fig. 6c) and sloshed it high up on the walls of the fuel-injector tank (Fig. 6b). As Fig. Ge indicates, $1.68 \mathrm{~kg}$ of the fuel froze as a crust on the walls of the fuel-injector tank. In the second phase, which began after the FCI-related pressurization subsided and the injection region of the test section voided, the remaining fuel was injected into the test section. Figures $6 \mathrm{f}$ and $6 \mathrm{~g}$ show the liquid velocities at the exit and inlet ends of the test section; because of the significant orificing at the inlet, the upward velocitias at the exit were of considerably greater magnitude than the downward velocities at the inlet. In Fig. jh, one can see the corresponding inlet and exit integrated fuel mass flow. 


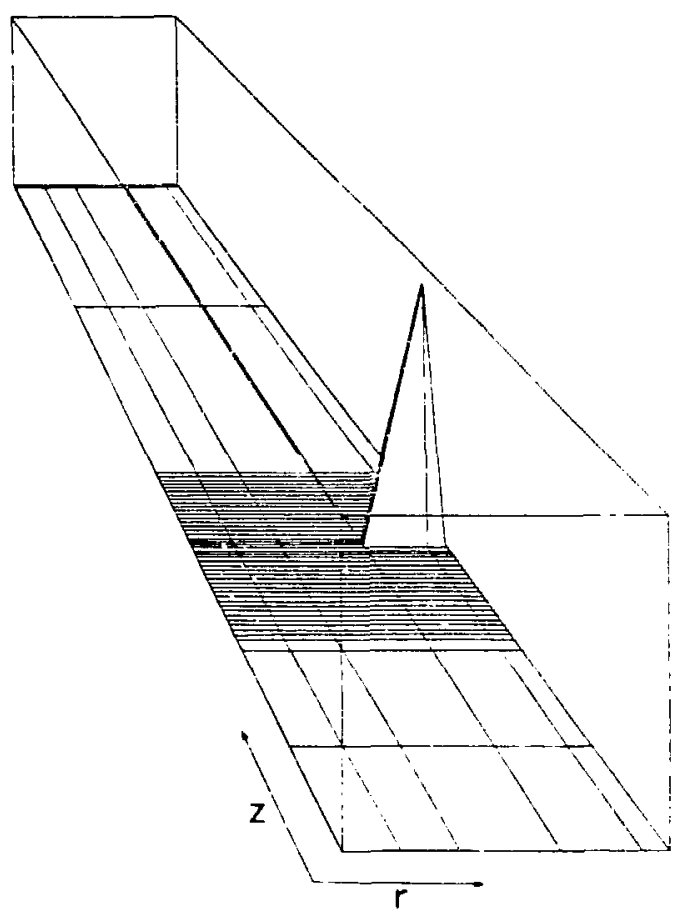

(a) Fuel macroscopic density $\left(\mathrm{kg} / \mathrm{m}^{3}\right)$ $(t=0.0 \mathrm{~s}, \operatorname{Min}=0, \operatorname{Max}=8860)$.

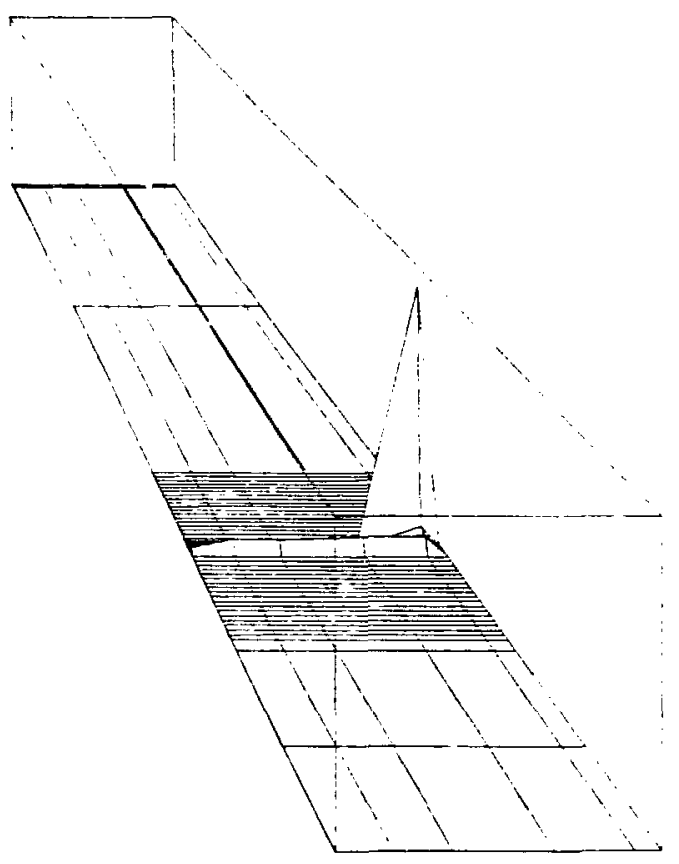

(c) Fuel macroscopic density $\left(\mathrm{kg} / \mathrm{m}^{3}\right)$ $(t=0.045 \mathrm{~s}, \operatorname{Min}=0, \operatorname{Max}=8860)$.

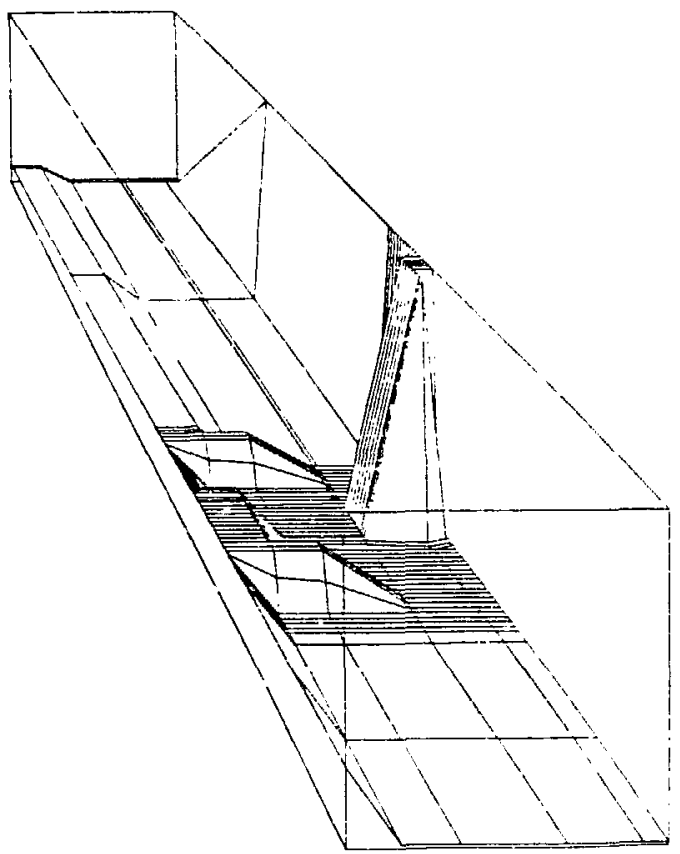

(b) Pressure (MPa)

$(t=0.0 \mathrm{~s}, \operatorname{Min}=0.00, \operatorname{Max}=0.75)$.

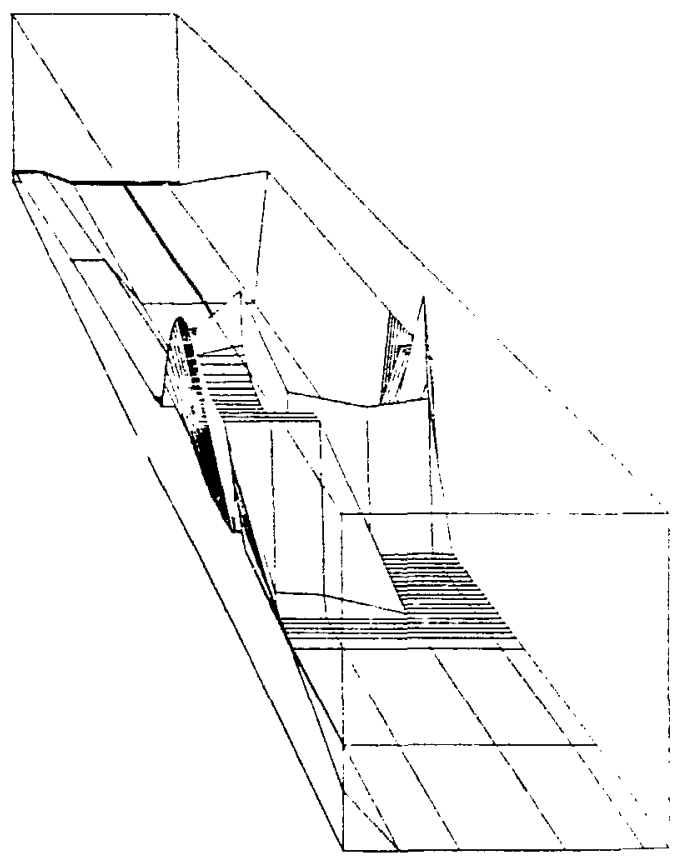

(d) Pressure (MPa)

$(t=0.045, \operatorname{Min}=0.00, \operatorname{Max}=1.11)$.

Fig. 5.

Various variables at selected times for C6 calculation (Case 1). 


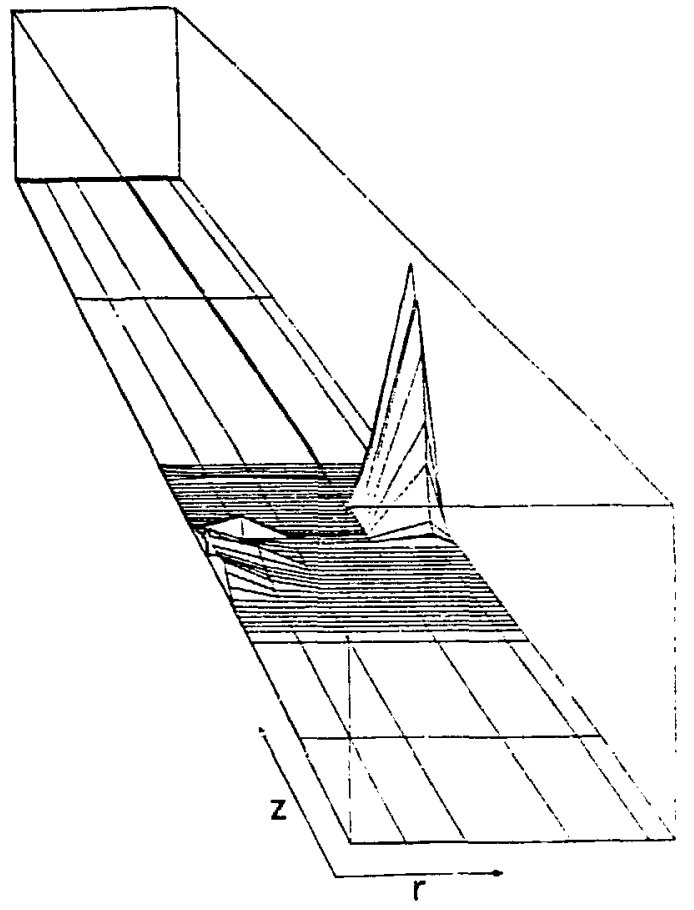

(e) Fuel macroscopic density $\left(\mathrm{kg} / \mathrm{m}^{3}\right)$ $(t=0.5 \mathrm{~s}, \operatorname{Min}=0, \operatorname{Max}=1120)$.

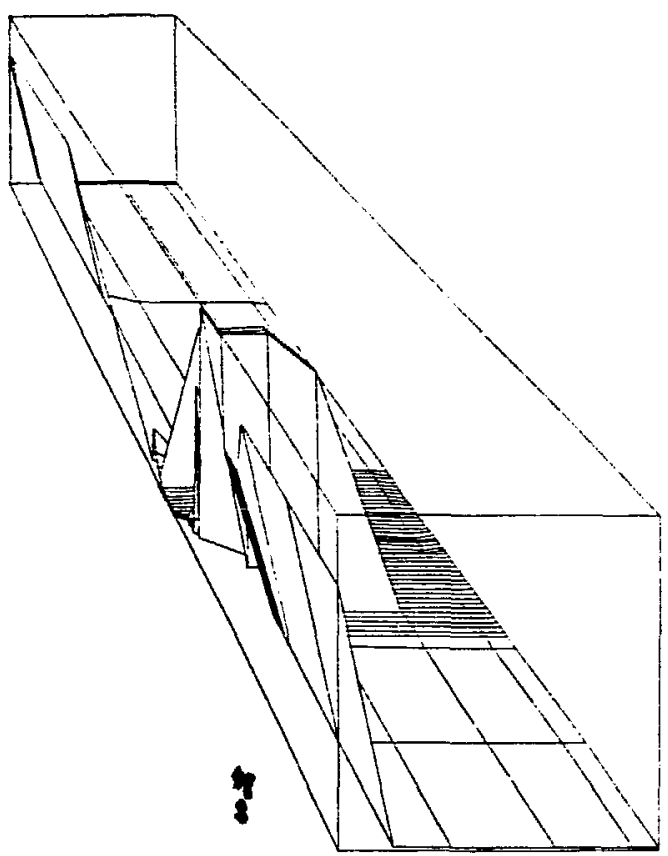

(g) Liquid sodium macroscopic density $\left(\mathrm{kg} / \mathrm{m}^{3}\right)$

$(t=0.5 \mathrm{~s}, \operatorname{Min}=0, \operatorname{Max}=832)$.

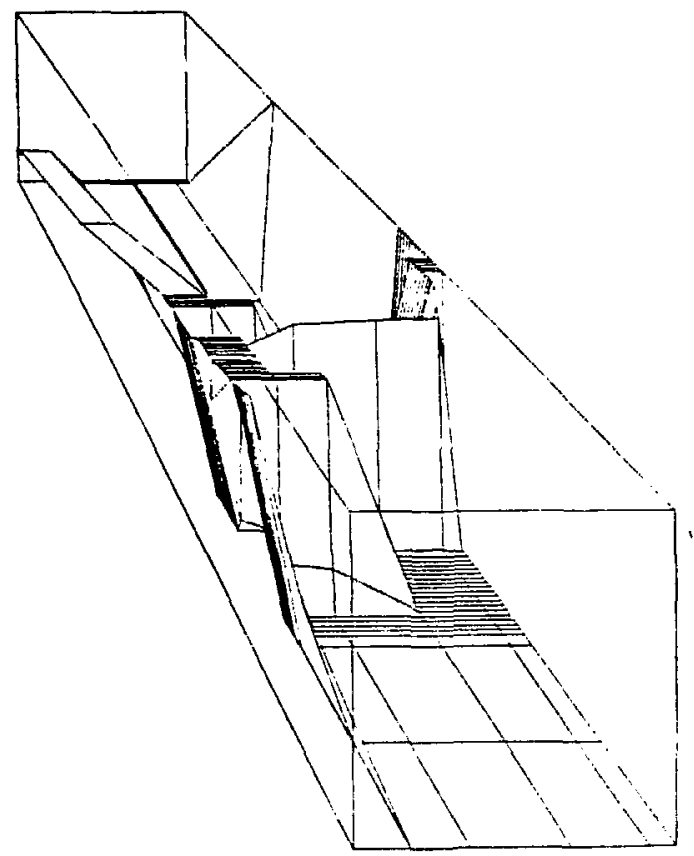

(f) Pressure (MPa)

$(t=0.5 \mathrm{~s}, \operatorname{Min}=0.01, \operatorname{Max}=0.49)$.

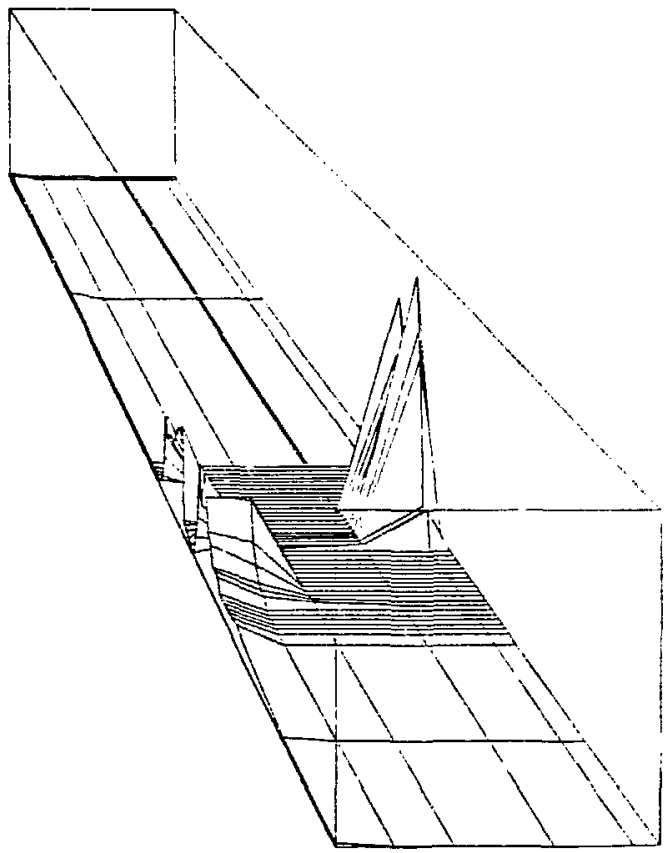

(h) Fuel macroscopic density $\left(\mathrm{kg} / \mathrm{m}^{3}\right)$

$(t=1.2 \mathrm{~s}, \operatorname{Min}=0, \operatorname{Max}=602)$.

Fig. 5. (cont)

Various variables at selected times for c6 calculation (Case 1). 

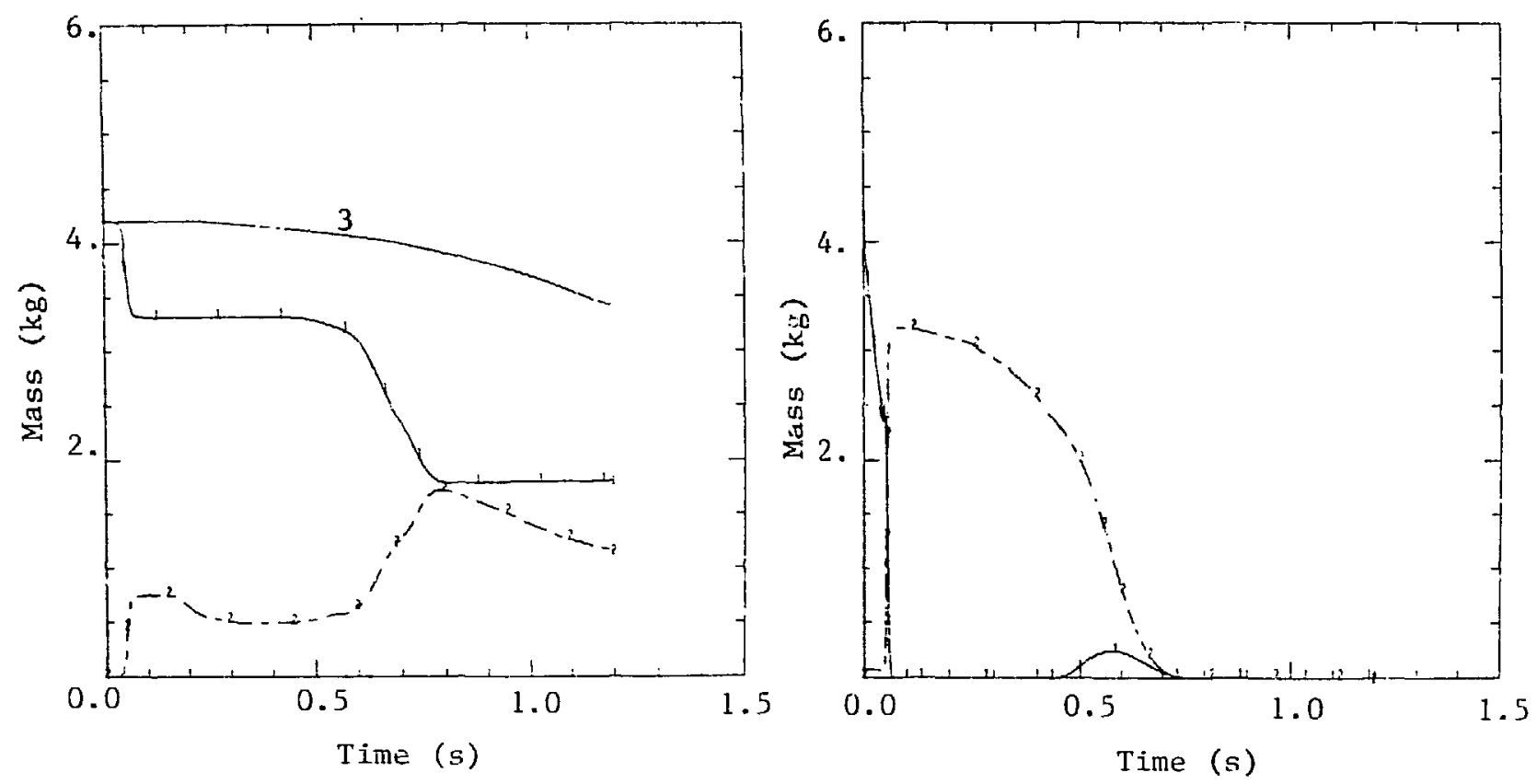

(a) Fuel mass
$(1=$ injector $2=$ test section:
$3=$ total system).
(b) Liquid fuel mass
$(1=$ lower fuel tank;
2 = upper fuel tank).
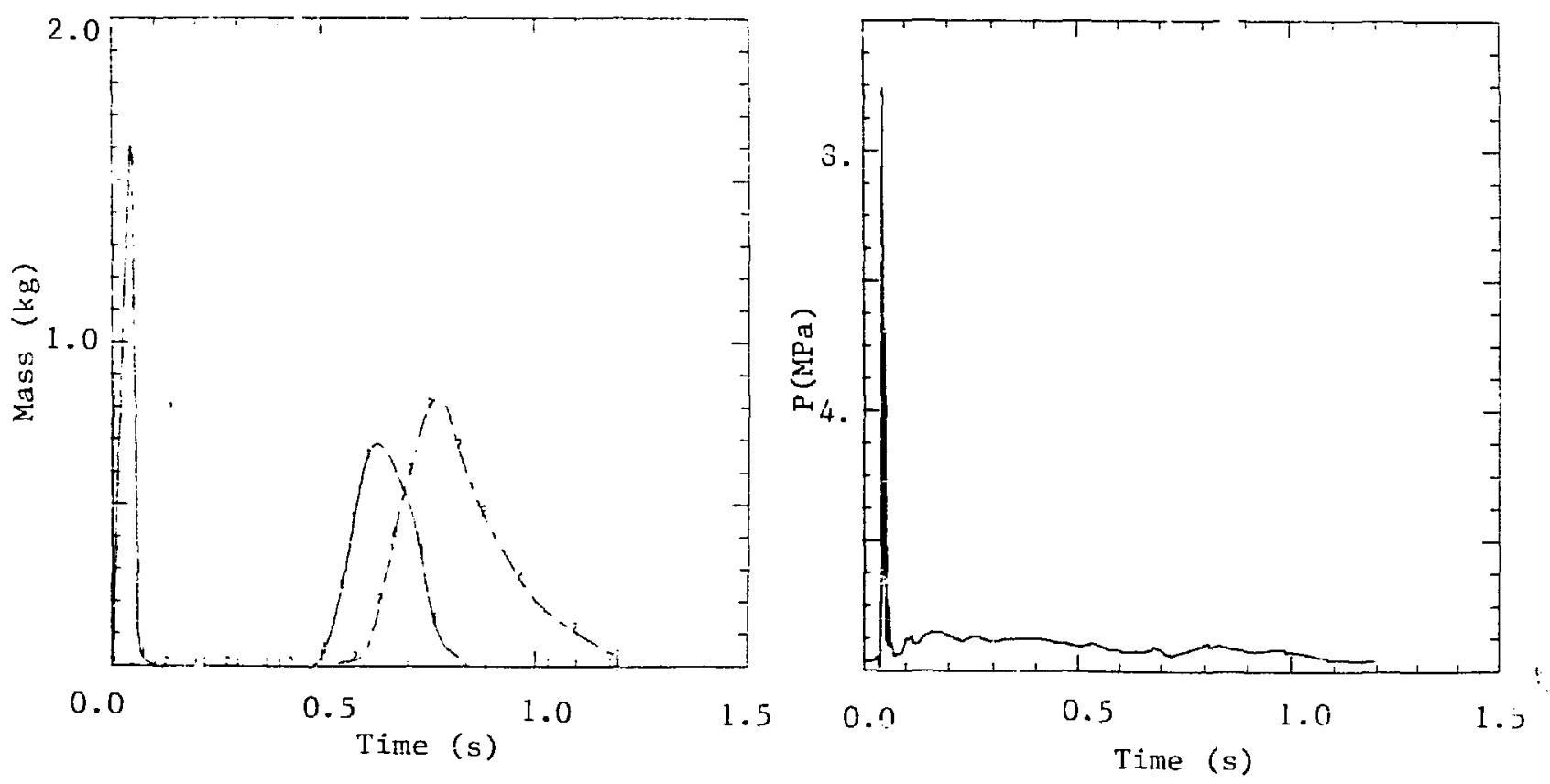

(c) Liquid fuel mass 11 = injector pipe;

(d) Pressure at the point of injection.

Fig. 6.

Time histories of selected variables for C6 calculation (Case 1). 


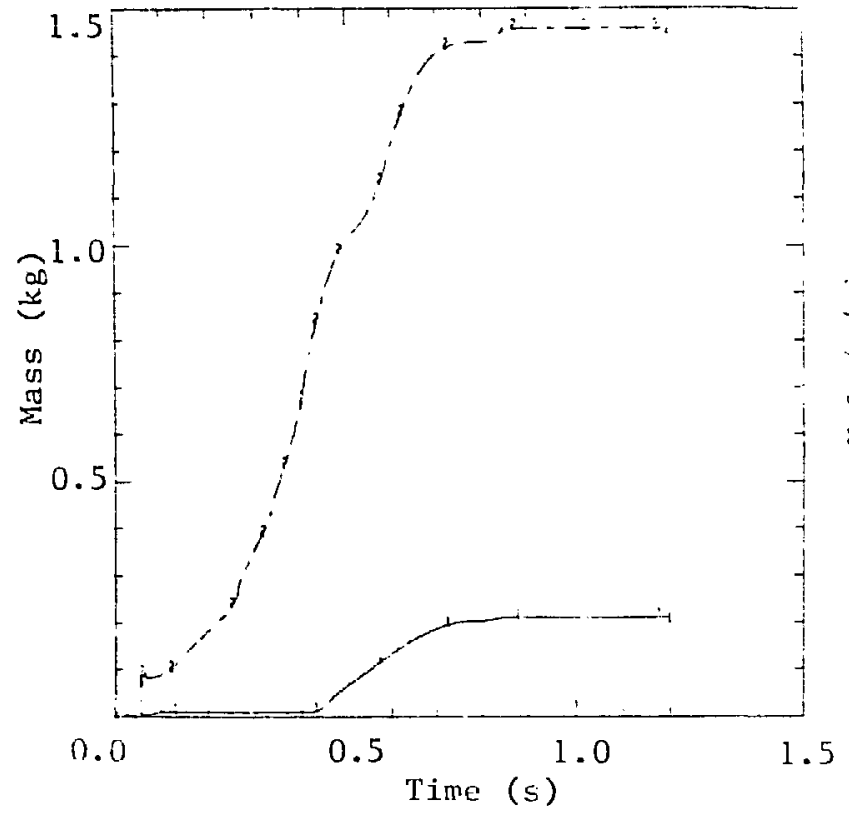

(e) Refrozen fuel

$(1$ = lower fuel tank;

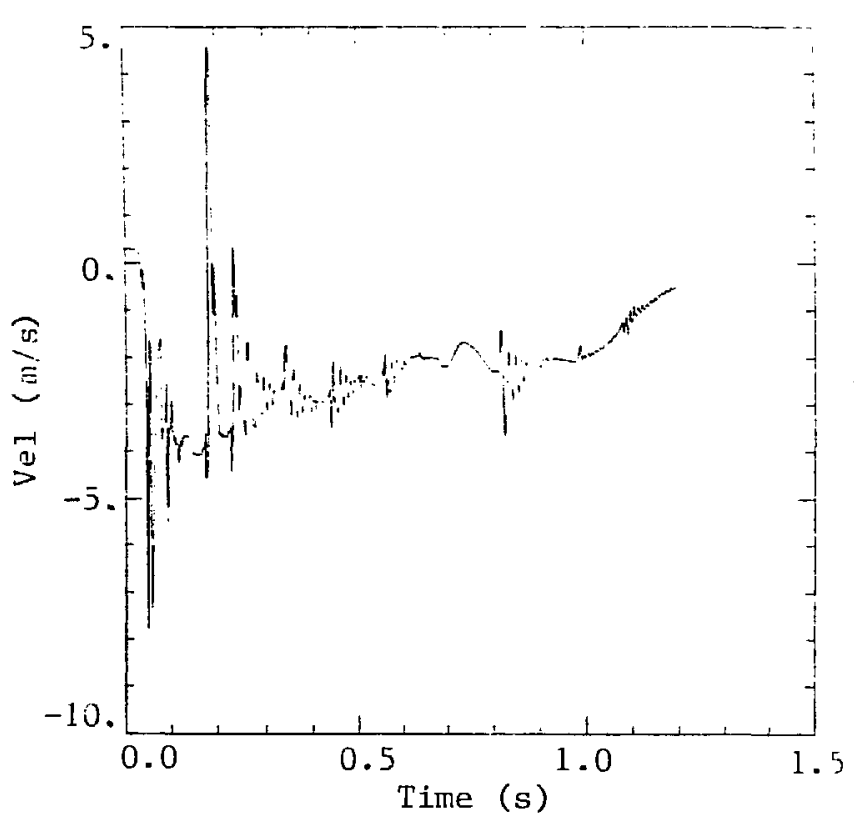

(g) Test-section inlet 1 iquid velocity.

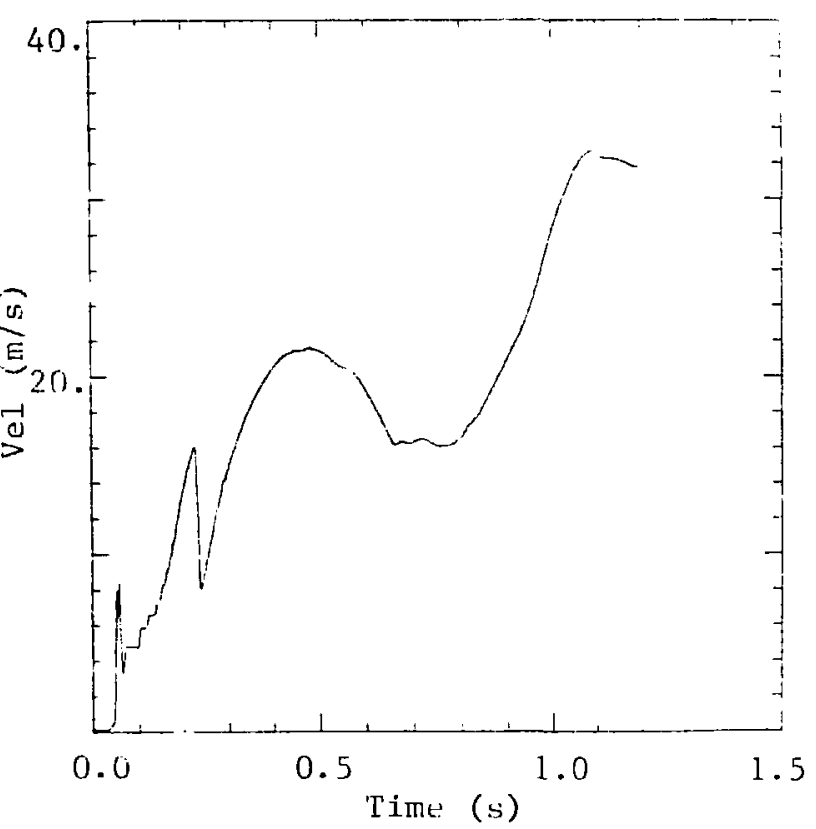

(f) Test-section exit liquid velocity.

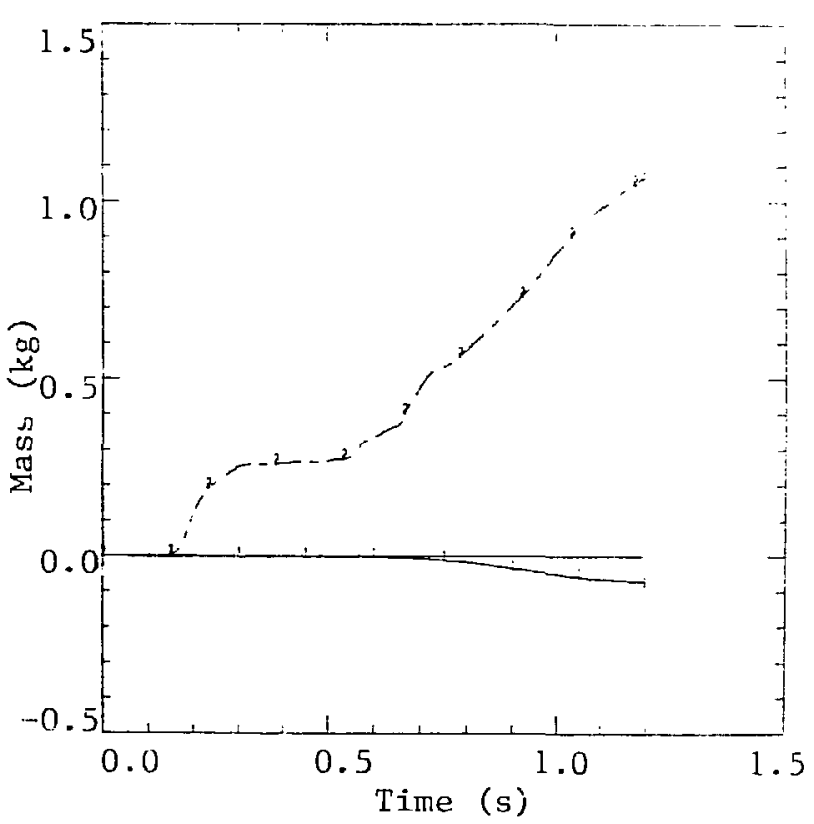

(h) Time-integrated fuel mass flow $(1=$ inlet; 2 = exit).

Fig. 6. (cont)

Time histories of selected variables for C6 calculation (Case 1). 
The $C 7$ calculation, with lower Ariving pressure and negative initial coolant velocity, proceeded very much like the $\mathrm{C} 6$ calculation. In this case, $2.39 \mathrm{~kg}$ of fuel was injected into the tast section (Fig. 7).

B. Parameter Variations

The following variations on the base case $C 6$ were performed. Liquid/liquid heat-transfer coefficients between liquid sodium coolant and liquid fuel (including fuel particles) were altered to determine whether changing the FCis would change the amount of injected fuel. Let $R_{11}$ stand for these heat-transfer coefficients for the base case $\mathrm{C} 6$; the additional cases run were with $R_{11} \times 10, R_{11} \times 10^{-1}$, and $R_{11} \times 10^{-9}$. In the latter case, the initial FCI was vanishingly small and, as expected, most of the fuel was injected.

In addition, three cases were calculated with $\mathrm{R}_{11}, \mathrm{R}_{11} \times 10$, and $\mathrm{R}_{11} \times 10^{-1}$, for which the initial inventory of fuel was cut in half to $2.1 \mathrm{~kg}$. The purpose was to simulate the experimental assumption that the thermite ignition process sloshed fuel into the upper fuel tank, where almost half of it froze on the

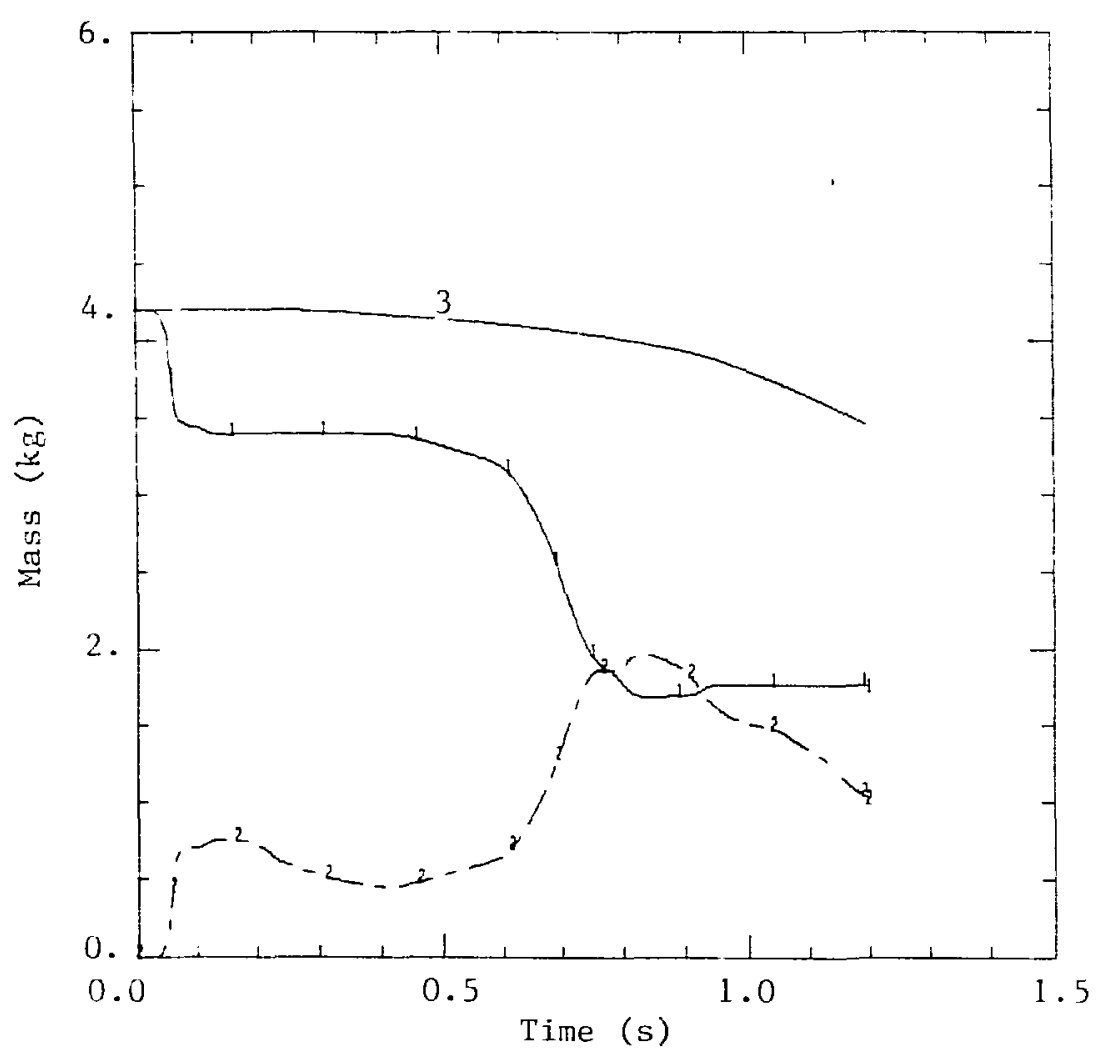

Fig. 7.

Fuel mass in $\mathrm{C7}$ test (Case 8)

$(1=$ injector $; 2$ = test section; 3 = total system $)$. 


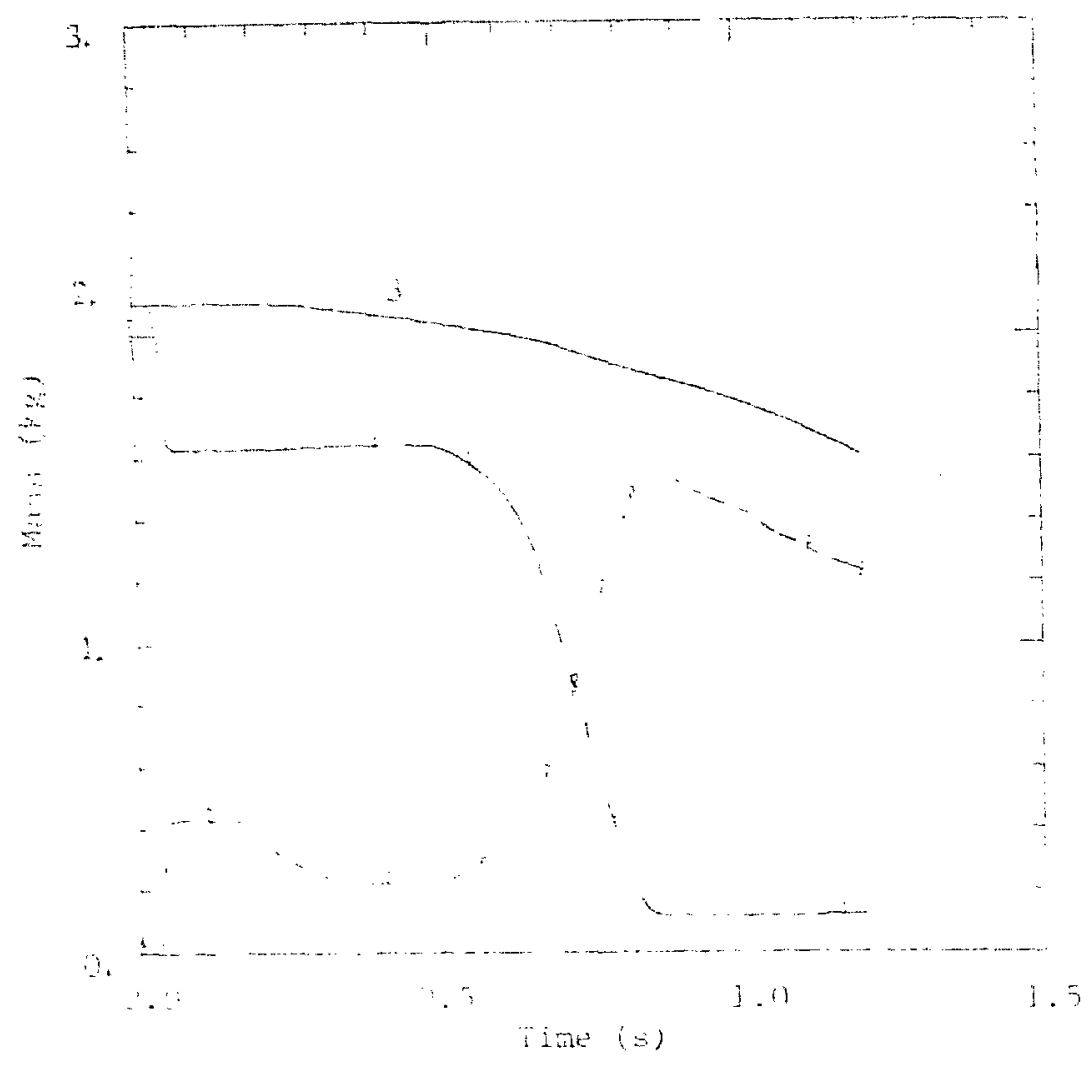

Fig. 8.

Fuel mass in C6 iest (Case 5)

$1=$ injector; 2 = test section; $3=$ total system).

walls. In this situation, the fuel crust would be at a nelativeiy high temperature and would reduce any further liquid-fuel-to-wall heat flow. Thus, in the SIMMER-II Calculation, the heat-transfer coefficient for the fuel-tank wall was reduced accordingly. In these cases, as Fig. 8 illustrates, there was again the early FCI that resulted in fuel being returned to the fuel tank. However, because of the very low effective heat transfer to the tank walls, only $0.02 \mathrm{~kg}$ of additional crust formed on the tank and $2.0 \mathrm{~kg}$ of fue? was injected into the test section.

In Table II are listed, for comparison, the cases calculated with SIMMER-II, the total mass of fuel injected, and the fractions of injected fuel that flowed up and down for each case. These quantities were not particularly sensitive to the variations. The exception was case 4, in which the heat-transfer multiplier was reduced to $10^{-9}$. The FCI was reduced such that only a third as much fuel was sloshed into the upper fuel tank and only a fifth as much formed crust there; $90 \%$ of the initial fuel was injected into the test section as is shown in Fig. 9 . 
TABLE II

\section{SIMMER-II CALCULATED CASES}

\begin{tabular}{|c|c|c|c|c|c|}
\hline $\begin{array}{l}\text { SIMMER } \\
\text { Case }\end{array}$ & $\begin{array}{l}\text { Test } \\
\text { Case } \\
\end{array}$ & $\begin{array}{l}\text { Fue } 1 \\
\text { Mass } \\
(\mathrm{kg}) \\
\end{array}$ & $\begin{array}{l}\text { Heat-Transfer } \\
\text { Multiplier }\end{array}$ & $\begin{array}{c}\text { Fuel } \\
\text { Injected } \\
(\mathrm{kg}) \\
\end{array}$ & $\begin{array}{c}\text { Fraction } \\
\text { Fuel Flow } \\
\text { Up } \\
\text { Down }\end{array}$ \\
\hline 1 & C6 & 4.2 & $10^{\circ}$ & 2.27 & $\begin{array}{l}0.65 \\
0.35\end{array}$ \\
\hline 2 & C6 & 4.2 & $10^{1}$ & 2.01 & $\begin{array}{l}0.70 \\
0.30\end{array}$ \\
\hline 3 & C6 & 4.2 & $10^{-1}$ & 2.58 & $\begin{array}{l}0.66 \\
0.34\end{array}$ \\
\hline 4 & C6 & 4.2 & $10^{-9}$ & 3.75 & $\begin{array}{l}0.52 \\
0.48\end{array}$ \\
\hline 5 & C6 & 2.1 & $10^{\circ}$ & 1.95 & $\begin{array}{l}0.76 \\
0.24\end{array}$ \\
\hline 6 & C6 & 2.1 & $10^{1}$ & 1.84 & $\begin{array}{l}0.66 \\
0.34\end{array}$ \\
\hline 7 & C6 & 2.1 & $10^{-1}$ & 1.77 & $\begin{array}{l}0.70 \\
0.30\end{array}$ \\
\hline 8 & $\mathrm{C7}$ & 4.2 & $10^{\circ}$ & 2.39 & $\begin{array}{l}0.66 \\
0.34\end{array}$ \\
\hline
\end{tabular}




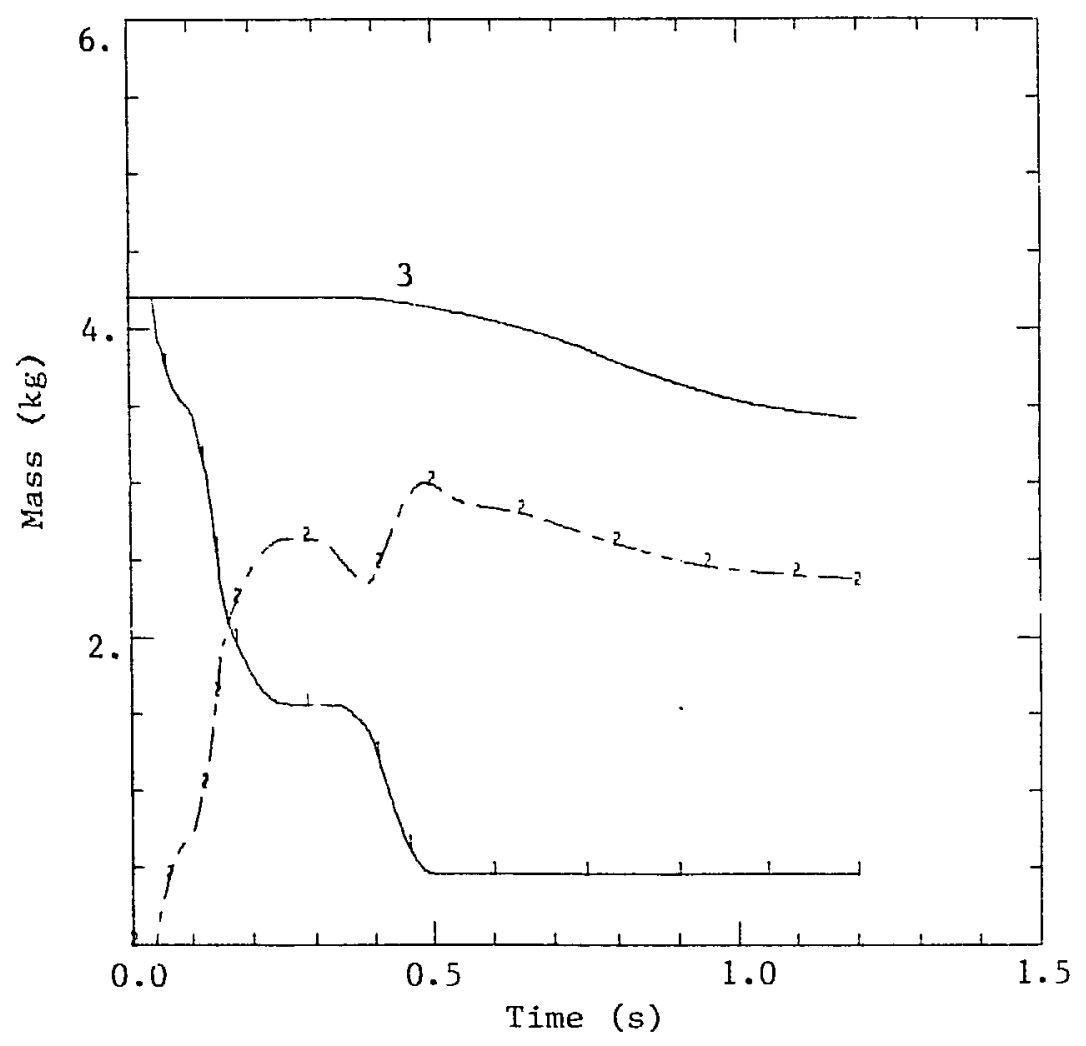

Fig. 9.

Fuel mass in C6 test (Case 4 )

$(1$ = injector; 2 = test section; $3=$ total system). 
IV. COMPARISONS WITH CAMEL II CS AND C7 EXPERIMENTS

In this section, comparisons of the SIMMER-II analyses with the experimental measurements wil1 be discussed.

\section{A. Mass Flow Comparisons}

Figures 10 and 11 show the total mass flow rates at the inlet and exit ends of the test section for the $C 6$ and $C 7$ tests. These figures compare the SIMMER-II base-case calculations (Case 1 and Case 3 ) of these tests with the experimental results. Although the fine-scale details differ, the overall agreement is very good. One significant difference is the experimental spike at $0.38 \mathrm{~s}$ in 66 and $0.57 \mathrm{~s}$ in $\mathrm{C7}$. This may be partly because of the asyrmetry of the real injector, which SIMMER-II must simuiate with azimuthal symmetry.

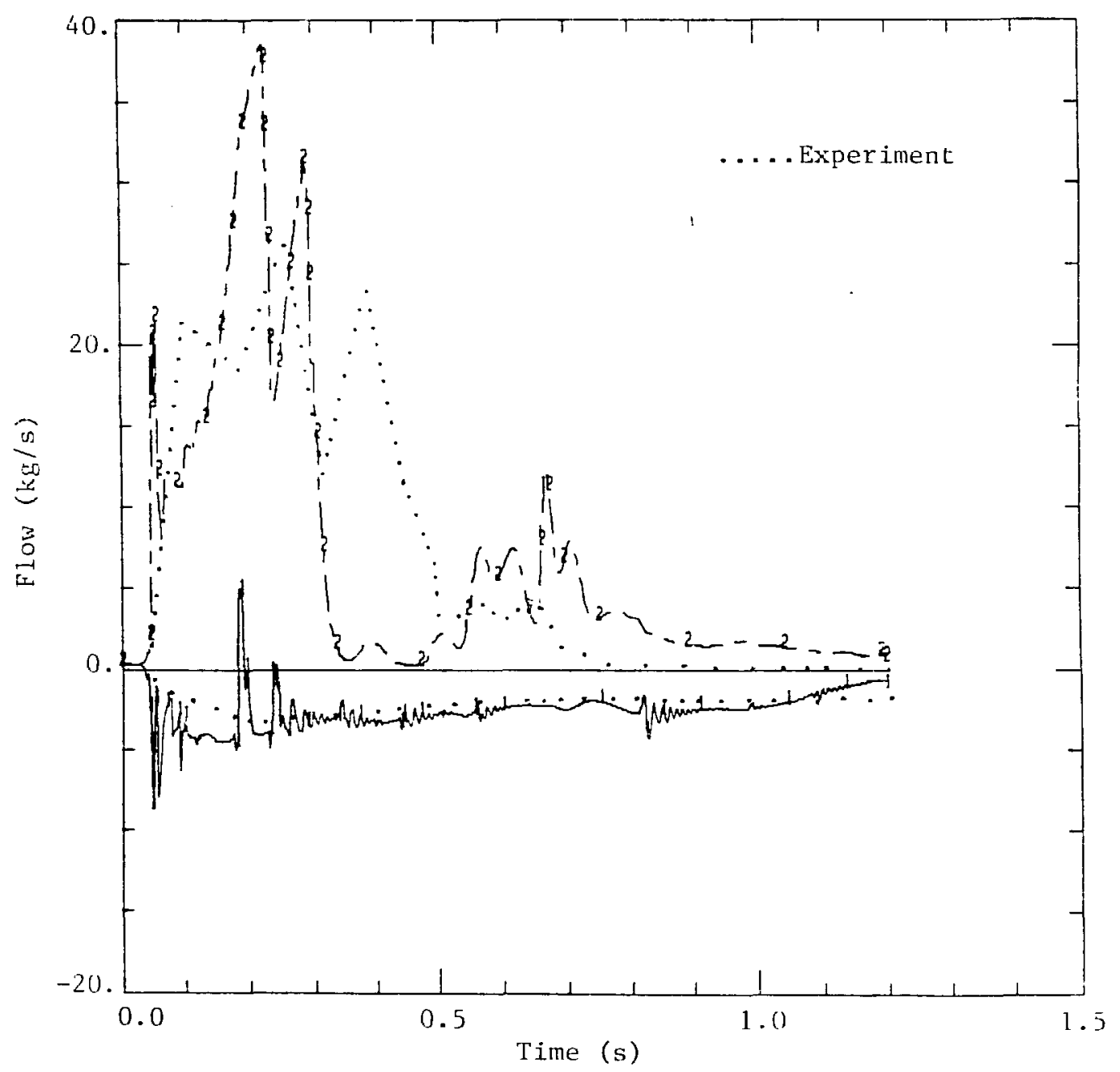

Fig. 10.

Total mass flow rates in 66 test (Case 1 )

$(1=$ inlet; 2 = exit). 
However, the best agreement between experiment and one of the SIMMER-II-calculated variations (Case 5 ) is shown in Fig. 12. These results indicate that possibly, curing the thermite reaction, some fuel was sloshed up to the upper fuel tank where about half the fuel inventory froze into crust, and that 1 ater, the injertion-point FCI drove the remaining fuel back up into the tank a second time, where the high-temperature fuel crust allowed little of it to freeze. It was finally injected into the fuel tank. Posttest examination of the experiments did verify that considerable fuel crust and debris were found in the fuel tank, but the experiments were not designed to determine the possibility of flow reversal in the injector pipes after the initial FCI.

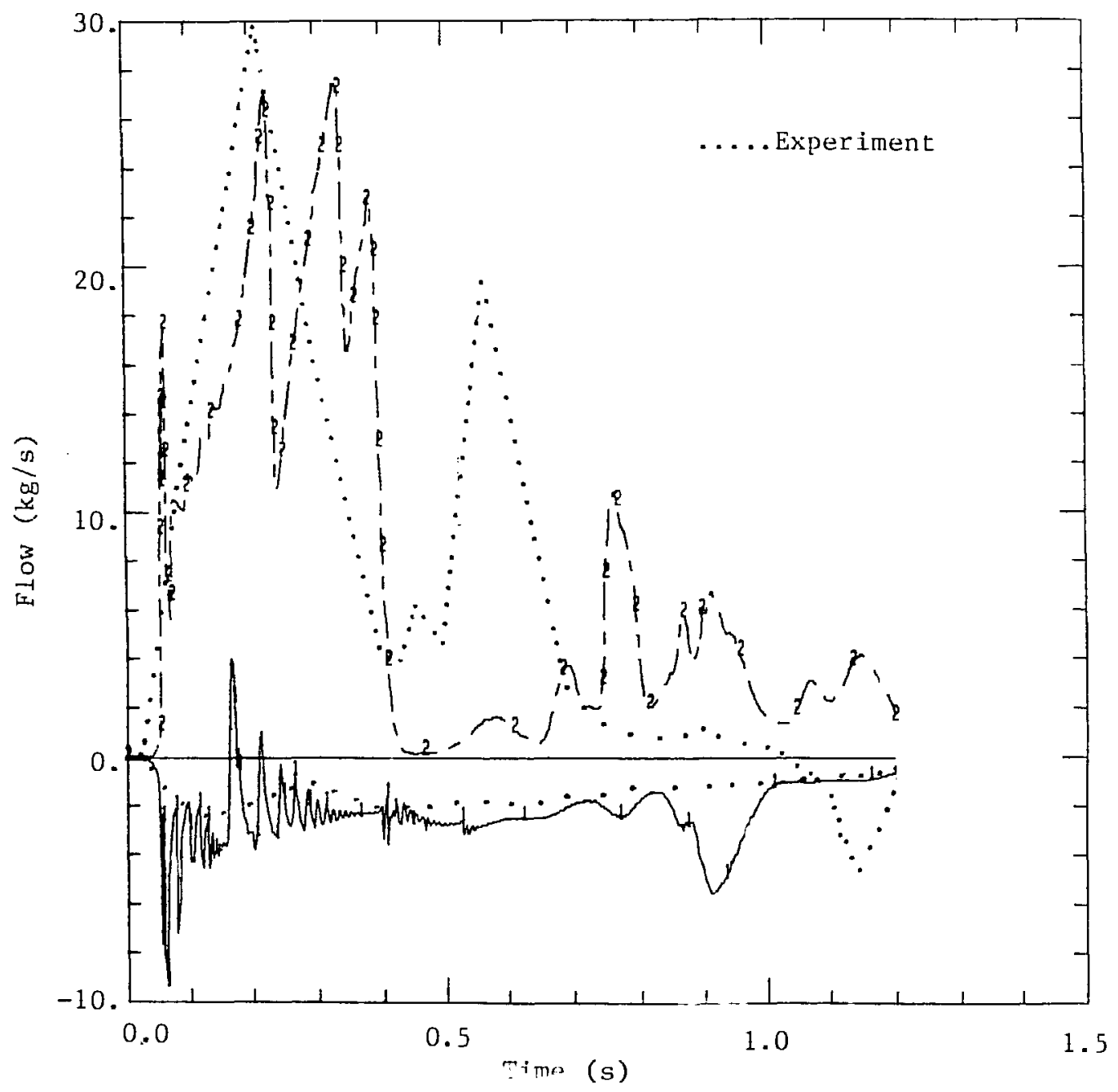

Fig. 11 .

Total mass flow rates in $\mathrm{C7}$ test (Case 8 )

$(1$ = inlet; 2 = exit). 


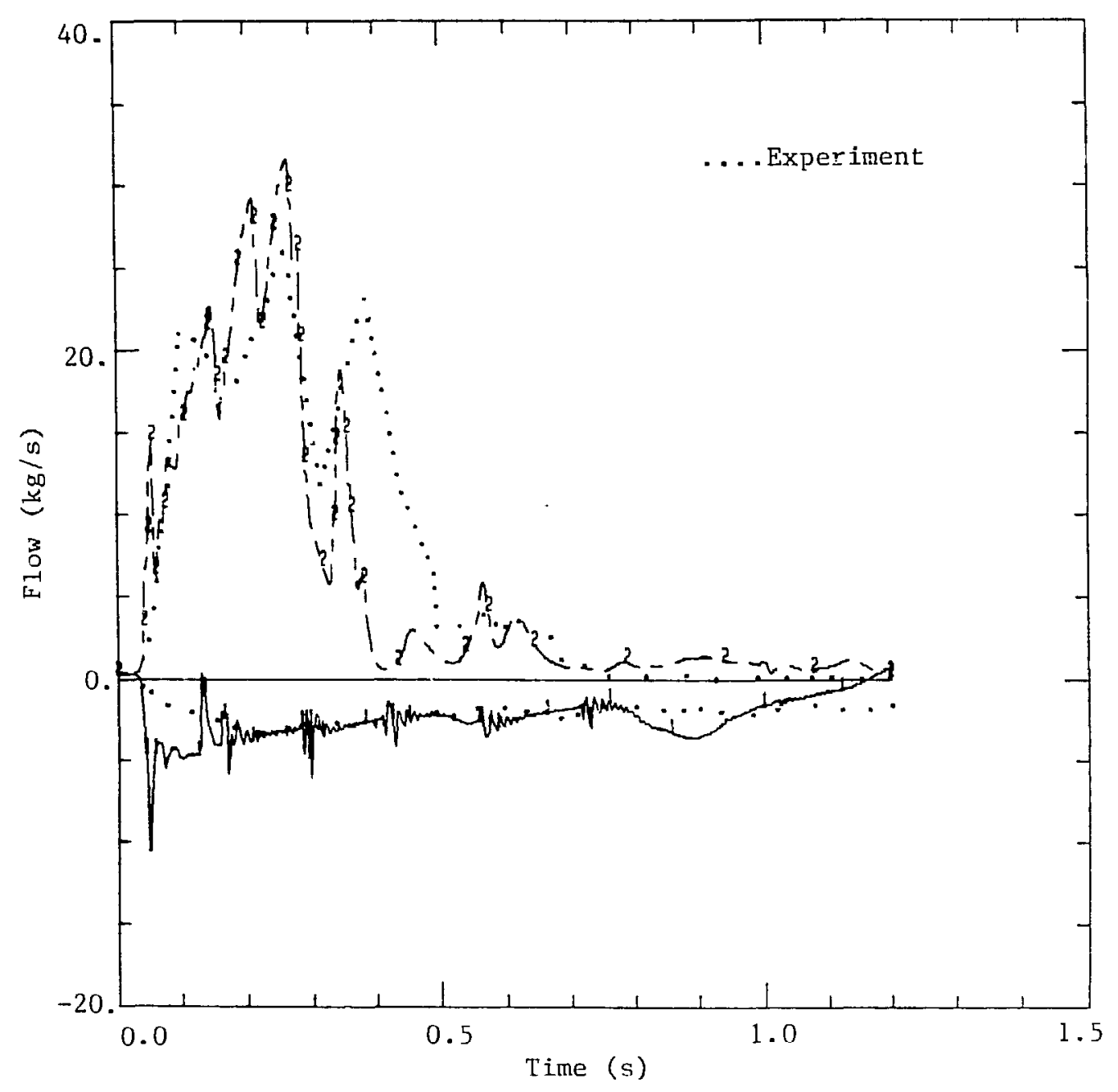

Fig. 12.

Total mass flow rates in 66 test (Case 5 )

$(1$ = inlet; 2 = exit). 


\section{B. Void Volume Comparisons}

Figure 13 illustrates the difficulty of directly tracking the location of the liquid-vapor interface locations created by the fuel-injection-induced sodium voiding in the test section. The interface chugging was caused by the following. The initial FCI formed pressurized sodium vapor, which caused the interfaces to move. Then some sodium condensed because of the cold test-section walls. The resulting decrease in pressure reversed the interface velocitites. The soijum moved back into hot fuel, causing more vapor production and pressurization. This cyclic process caused the chugging. The experimentalists also had difficulty in tracking the interface locations because injected fuel shorted out their voltage taps when it made contact with the test-section back wall.

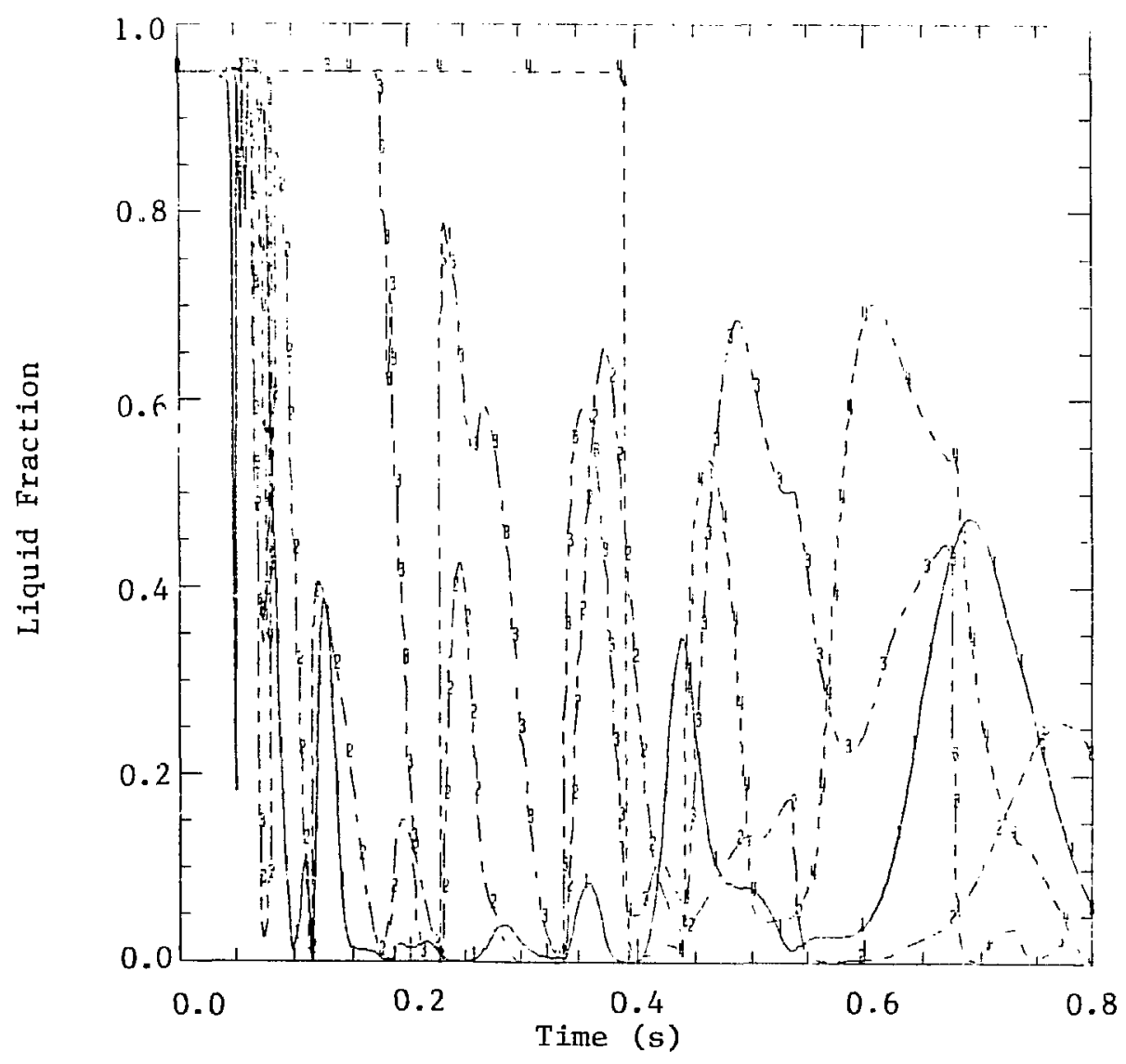

Fig. 13.

Motion of the liquid-void interface (Case 1) for axial cells $23,22,21$, and 20 (labeled $1,2,3$, and 4 , respectively). 
An estimation of the experimental total void volume $V(t)$ was made by integrating the flow meters responses $\dot{m}$, that is,

$$
V(t)=\frac{1}{\rho} \int_{0}^{t} m_{E x i t} d t-\frac{1}{\rho} \int_{0}^{t} m_{I n 1 e t} d t, \quad t<\text { exit void time. }
$$

Similarly, an estimation of $V(t)$ can be made with the SIMMER-II results,

$$
V(t)=\int_{0}^{t}\left(A v_{l}\right)_{E x i t} d t-\int_{0}^{t}\left(A v_{l}\right)_{I n l e t} d t, \quad t<\text { exit void time, }
$$

where $A$ is the test-section cross-sectional area and $v_{\ell}$ is the sodium velocity. Figures 14 and 15 show the comparisons for the $C 6$ and $C 7$ cases. The comparisons are sensible only unitil the time at wich the void interface reaches the test-section exit; this occurs earliest in. the SIMMER-II calculations and is indicated by a tick mark on the time scale of the figures. After that time, the curves would be expected to diverge because the flow meters read vapor mass flow, whereas in the SIMMER-II calculations, there is always some 1iquid present even in the void.

As a further analysis of the void growth, the experimental inlet interface position was generated from the inlet flow meter,

$$
L=\frac{1}{\rho A} \int_{0}^{t} \dot{m}_{\text {Inlet }} d t \text {, }
$$

or, in the SIMMER-II calculations,

$$
L=\int_{0}^{t} v_{\ell} d t
$$

The comparison is shown in Fig. 16 for both the $\mathrm{C} 6$ and $\mathrm{C7}$ tests. Again, the agreement is fairly good, although tine inlet interface does move down faster in the SIMMER-II calculations. Furthermore, consideration of the parameter variations in the SIMMER-II calculations shows that neither the magnitude of the initial FCI nor the lack of a detailed treatment of the thermite reaction plays an important role in the sodium voiding. 


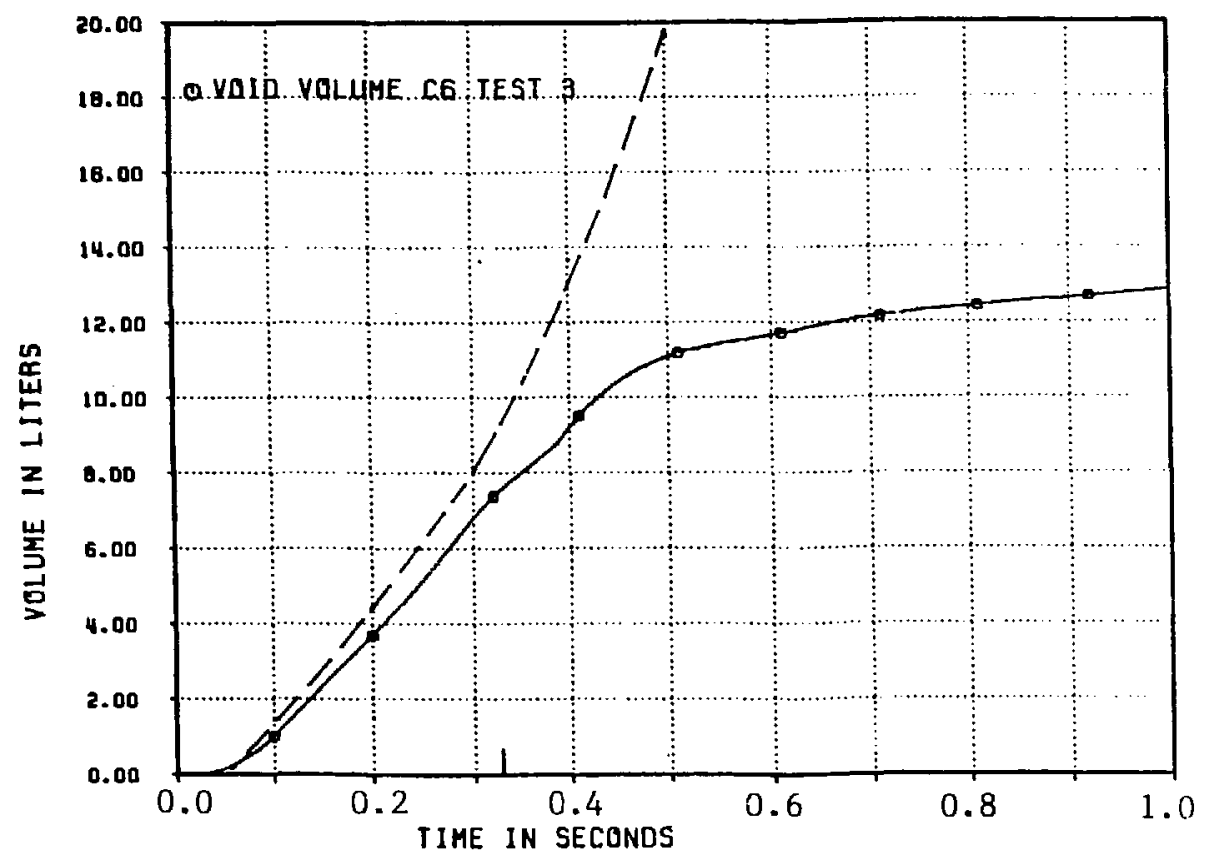

Fig. 14.

Sodium void volume history, 66 test

(dashed curve represents SIMMER-II Case 1 calculation).

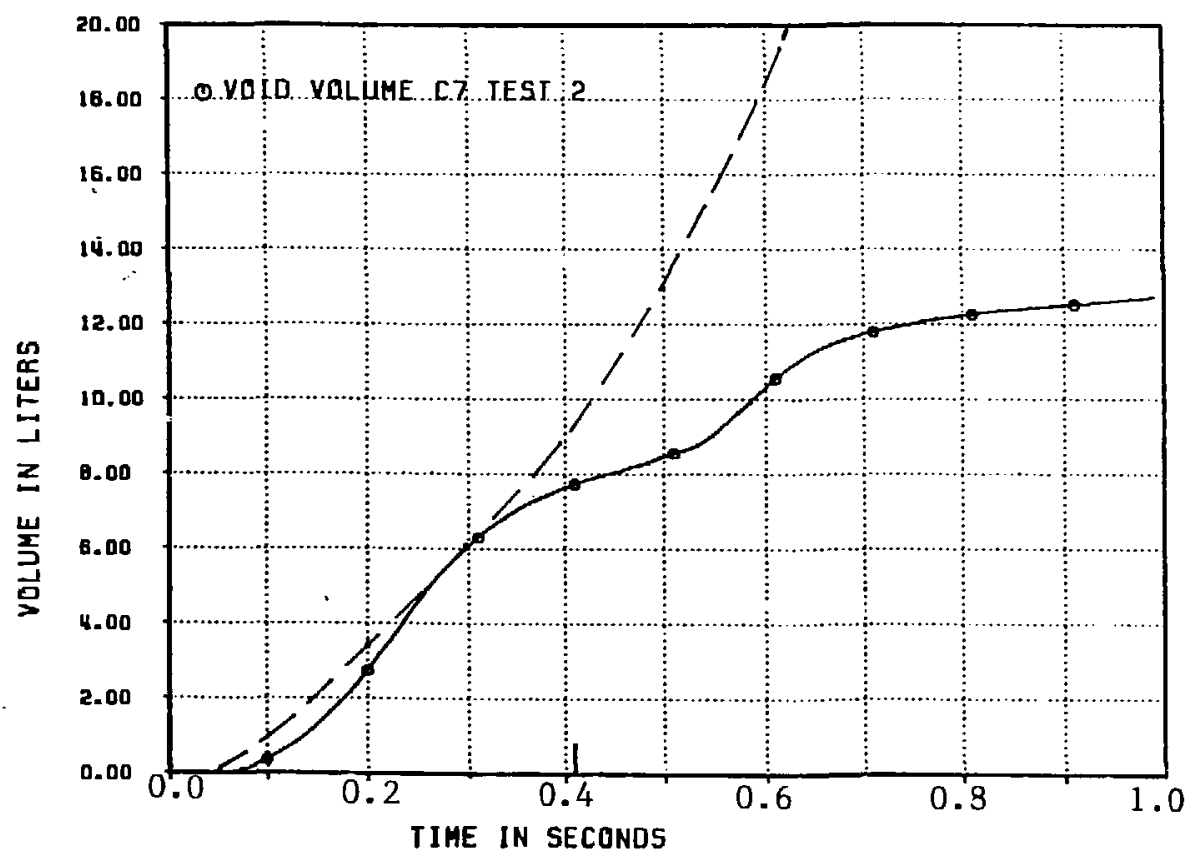

Fig. 15.

Sodium void volume history, $\mathrm{C} 7$ test 


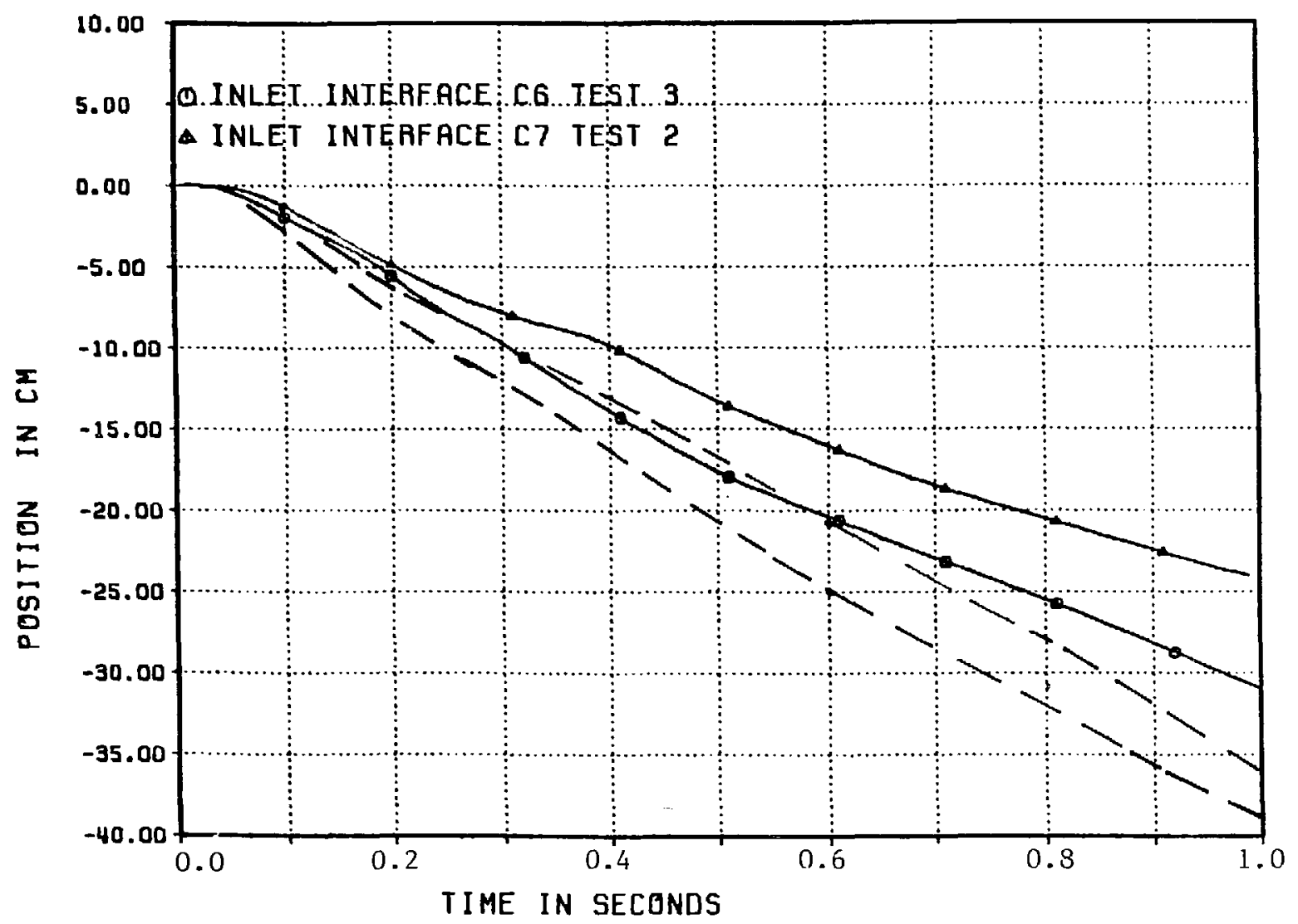

Fig. 16 .

Inlet interface position for $\mathrm{C} 6$ and $\mathrm{C} 7$ tests

(dashed curves represent SIMMER-II Case 1 and Case 8 results).

\section{Pressure Response Comparison}

Figures 17 and 18 show the experimental and the calculated inlet flow and pressure traces at $11.0 \mathrm{~cm}$ below the injection point in the test section. These figures are not meant for direct comparison both because of experimental difficulties in obtaining accurate measurements and because of calculational difficulties in ascertaining precise maxima and widths of very sharp pressure pulses. However, they do indicate that the more rapid accelerations of the inlet flow are correlated with FCI pressure events. 


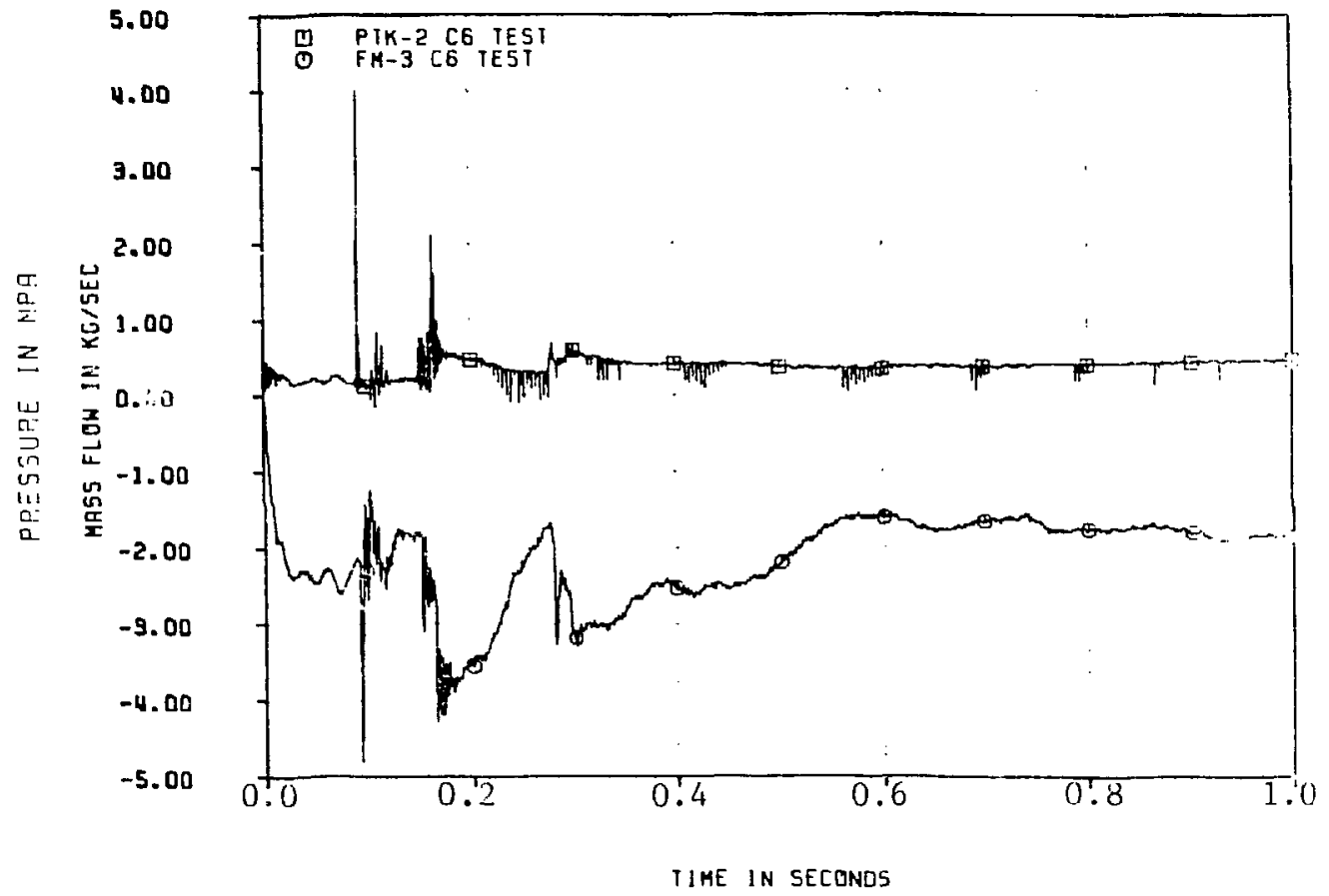

Fig. 17.

Experimental pressure (PTK-2) and inlet flow (FM-3), C6 test.

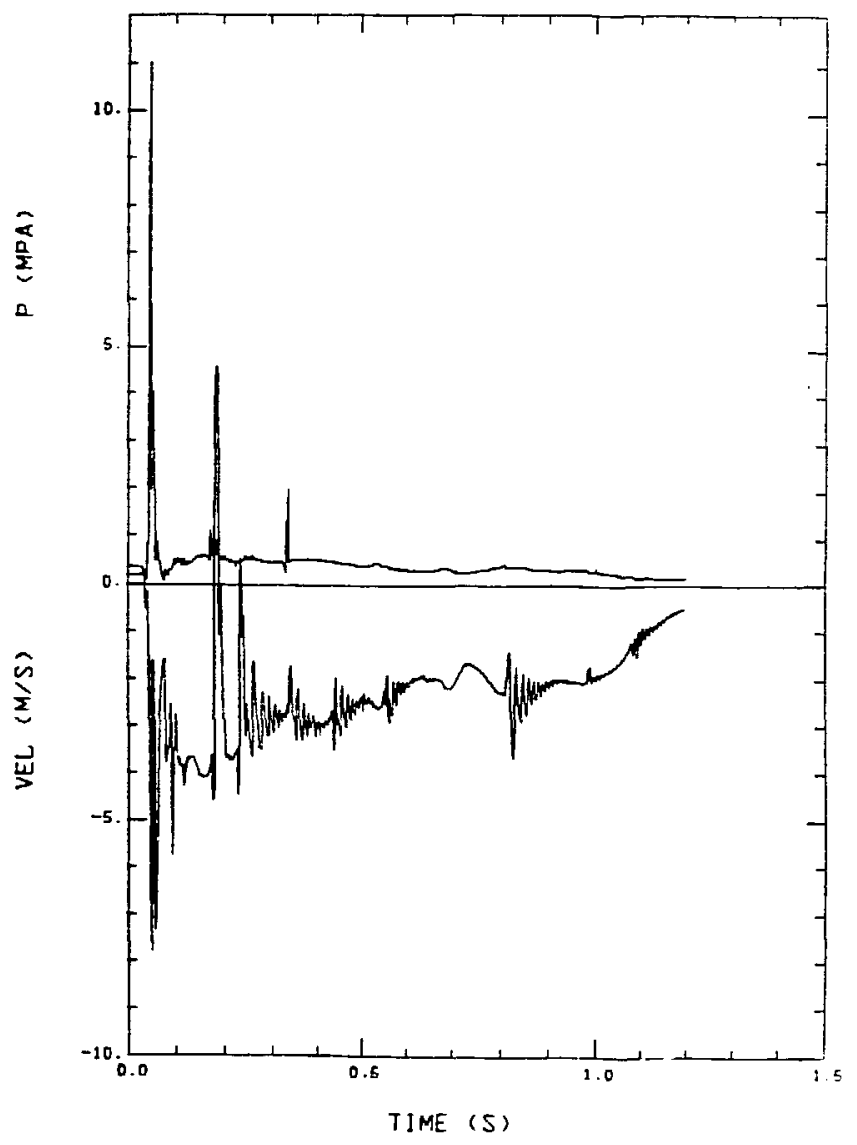

Fig. 18.

SIMMER-II pressure and flow $11 \mathrm{~cm}$ beiow injection point, c6 test (Case 1). 
The ANL CAMEL II C6 and C7 test sections contained traps (Fig. 2) that collected and held any fuel particles that flowed into them. After the experiments, which lasted some $30 \mathrm{~s}$, this material was examined and weighed. Because the particle traps were located above and below that portion of the test section that corresponded to the active core region, this examination allowed determination of the amount of injected fuel that was relocated away from the active core.

The collecting property of the particle traps was not explicitly modeled in the SIMMER-II calculations. Furthermore, as the SIMMER-II calculations were over in $1.2 \mathrm{~s}$, comparisons may not be accurate because there may have been some fallback of upper test-section particles in the experiments. Figures 19, 20, and 21 show the time history of the SIMMER-II results for three cases, Case 1 (c6 test with $4.2 \mathrm{~kg}$ fuel inventory), Case 5 (c6 test with $2.1 \mathrm{~kg}$ fuel inventory), and Case 8 (C7 test with $4.2 \mathrm{~kg}$ fuel inventory). In these figures, (a) shows, at any time, the amounts of injected fuel that flowed upward and downward from the injection point; (b), (c), and (d) show, respectively, the amounts of liquid fuel, fuel particles, and refrozen fuel in the upper and lower test sections. These three cases show similar trends for the injected fuel with some variation in the relative quantities dispersed up and down in the test section.

Table III allows some comparisons of injected fuel distribution. The largest disparity is in the comparison of the amounts of fuel frozen onto the walls. The experiments indicate that more than half the injected fuel was refrozen, whereas the calculational results gave a much lower anount. This would seem to indicate that the SIMMER-II modeling of the partition of fuel/coolant/wall heat transfer needs some adjustment. In addition, the experiments showed a maximum in plate-out on the test-section wall opposite the injection point that decreased both azimuthally and axially. The axial distribution was localized from $11.2 \mathrm{~cm}$ below to $21.8 \mathrm{~cm}$ above the injection point. SIMMER-II could not predict the azimuthal dependence and, because of numerical diffusion, predicted a somewhat greater axial region. Also, it appeared that in the 67 experiment, with its lower injection driving pressure, that the FCIs were milder and gravity played a greater role in causing more of the particles to appear in the lower trap. However, as previously mentioned, some of the disparity with the $C 7$ calculation might have been resolved by particle faliback had the calculation been extended in time. 


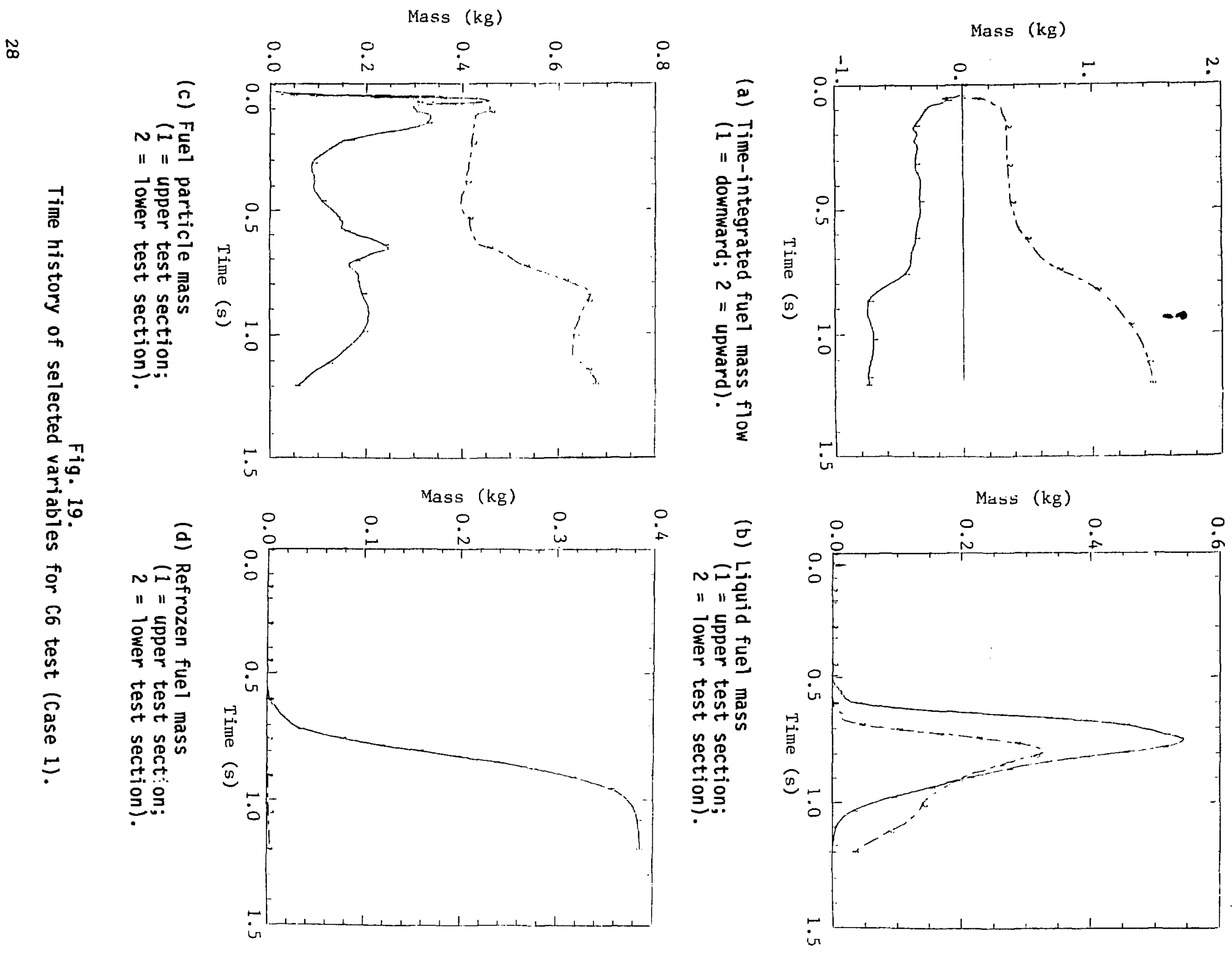



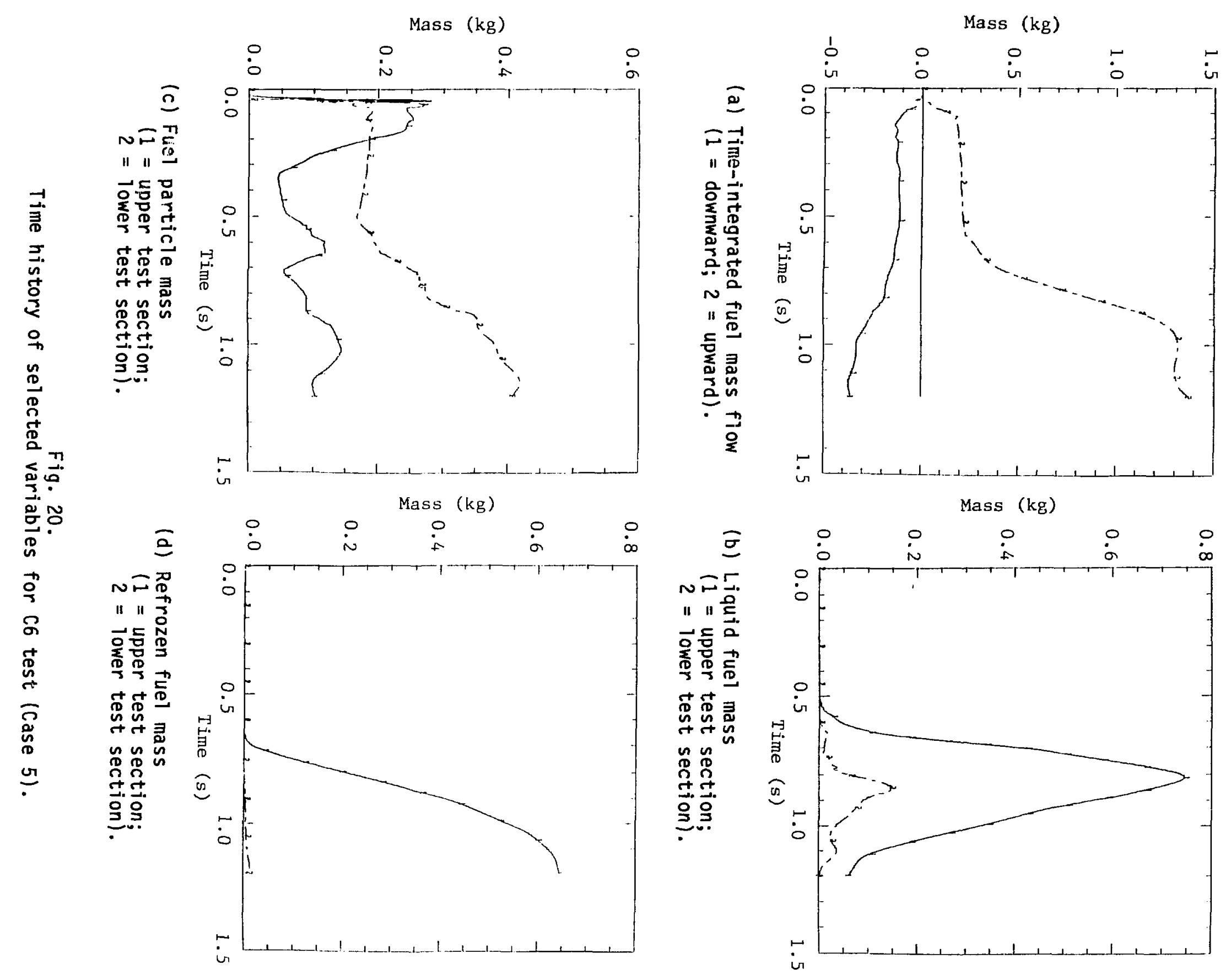

N

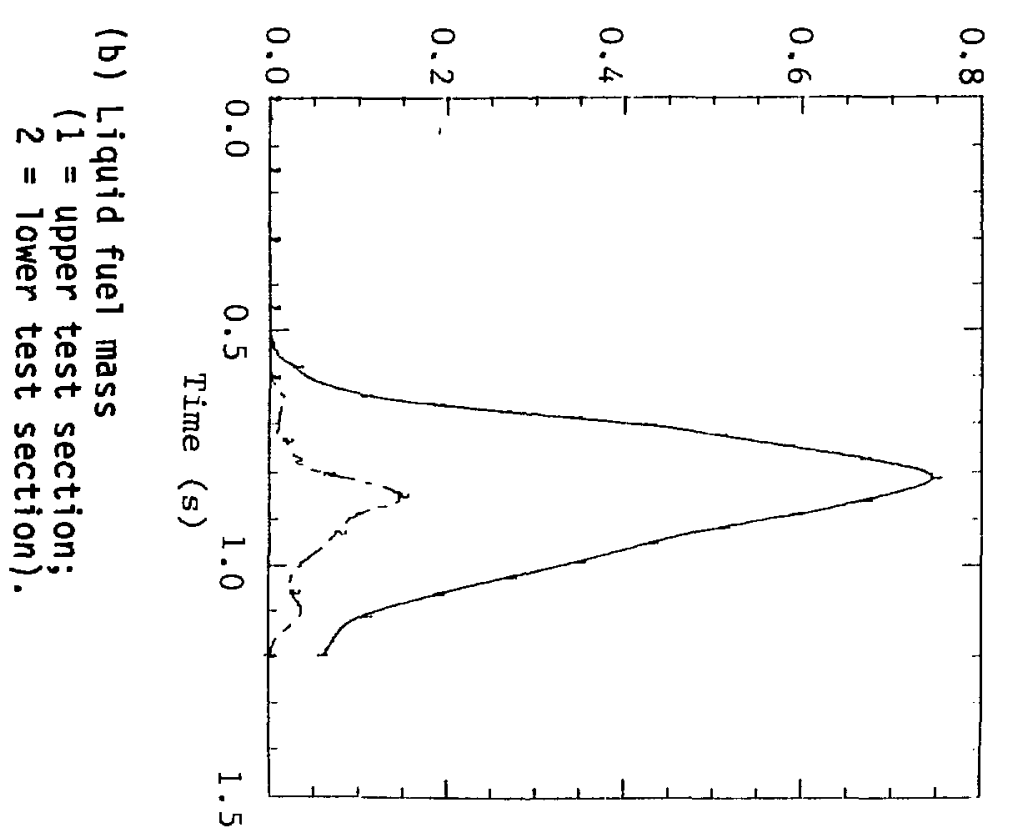


w

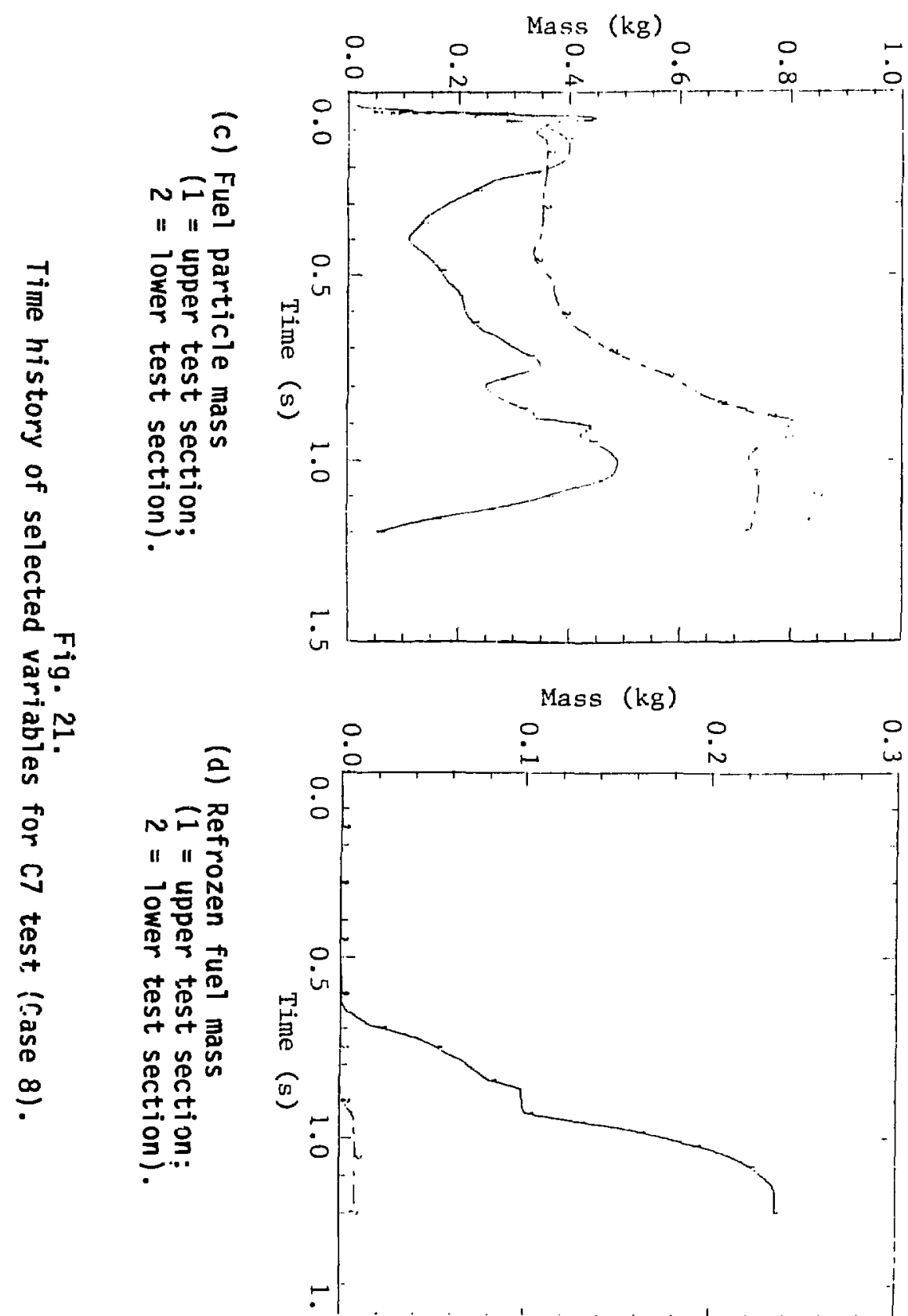

Mass (kg)
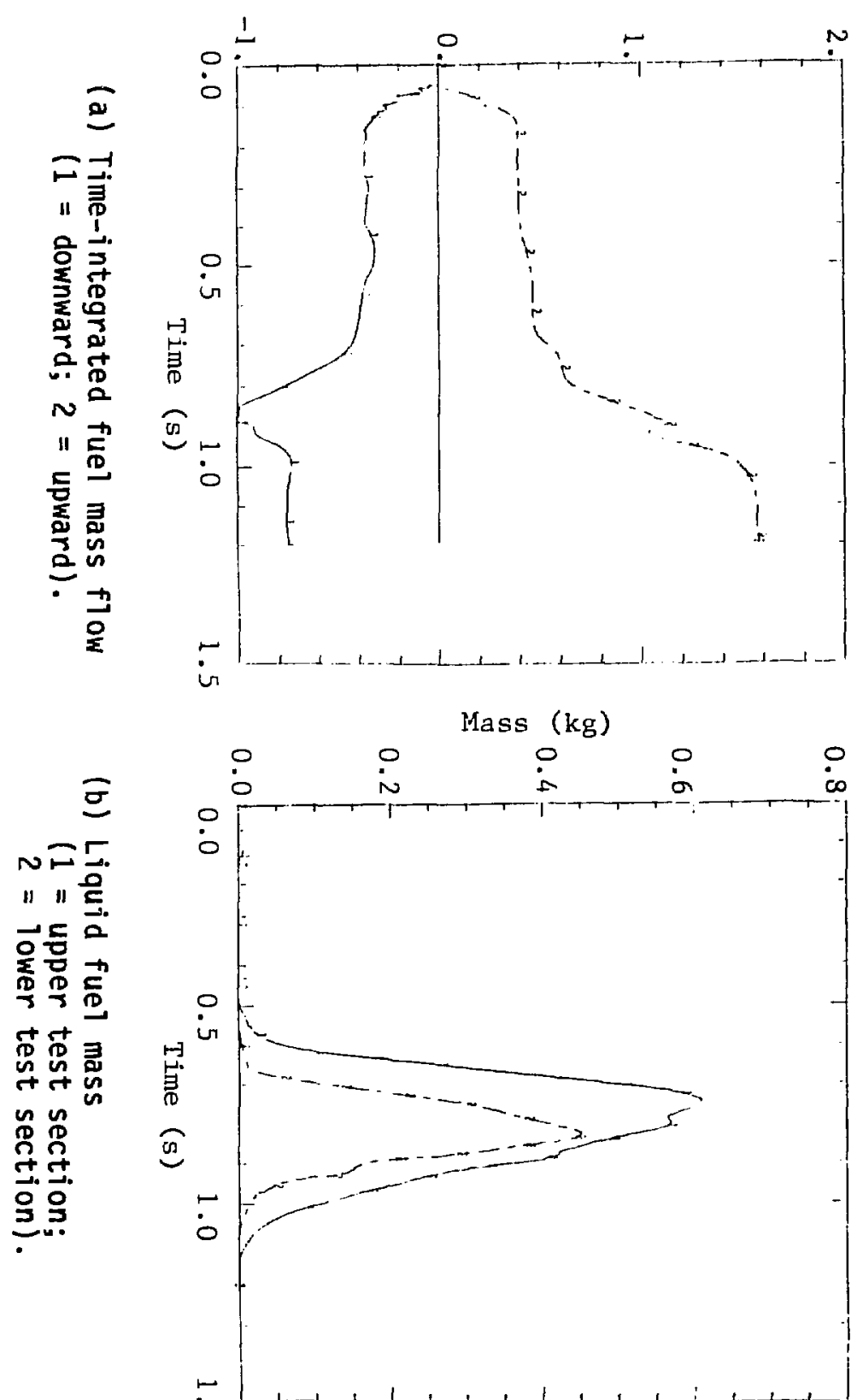
TABLE III

DISTRIBUTION OF INJECTED FUEL

Experimental

Fraction of particles recovered

from upper trap

C6 Test

0.63

0.37

from lower trap

Fraction of injected

fuel that froze on walls

SIMMER II Calculations

Fraction of injected fuel

that flowed upward

Fraction of injected fuel

that flowed downward

Fraction of injected fuel

that froze on walls

$$
\begin{array}{cc}
\frac{\text { C6 Test }}{(4.2 \mathrm{~kg}, 2.1 \mathrm{~kg})} & \text { C7 Test } \\
0.66,0.79 & 0.67
\end{array}
$$

$0.34,0.21 \quad 0.33$

$0.17,0.11 \quad 0.10$

\section{v. CONCLUSIONS}

With the aid of SIMMER-II, the ANL CAMEL II C6 and C7 tests have been modeled and analyzed. The calculations and preliminary analyses, that is, results presented to the ANL CAMEL II experimentalists, were made with no a priori knowledge of the experimental results. Even though, contrary to the experiments, the calculations were by necessity azimuthally symmetric, comparisons of the two were generally quite acceptable. It was concluded that areas of rather minor disagreement could have been eliminated with some fine-tuning of the SIMMER-II characterization of FCI magnitude and of the relative partitioning of fuel/coolant/structure heat transfer. It was further concluded that PCAs can considerably reduce the fuel mass in the active core of an LMFBR undergoing an HCDA, and that the earlier SIMMER-II analysis of this reactor problem ${ }^{4}$ was a credible analysis. 


\section{REFERENCES}

1. L. L. Smith, "SIMMER-II: A Computer Program for LMFBR Disrupted Core Analysis," Los Alamos Scientific Laboratory report NUREG/CR-0453, LA-7515-M (October 1978).

2. L. B. Luck, G. P. DeVault, M. W. Asprey, and C. R. Bel1, "An Evaluation of the Calculated Results of an Unprotected Transient Undercooling Accident in a Large, Heterogeneous-Core, Liquid-Metal-Cooled Fast Breeder Reactor," Los Alamos National Laboratory report NUREG/CR-3031, LA-9553-MS (December 1982).

3. T. G. Theofanous and C.R. Bell, "An Assessment of CRBR Core Disruptive Accident Energetics," Los Alamos National Laboratory report NUREG/CR-3224, LA-9716-MS (March 1984).

4. G. P. DeVault, "Intersubassembly Fuel Penetration into a Failed Primary Control Subassembly in an LMFBR," Los Alamos National Laboratory report LA-9952-MS (January 1984).

5. R. J.Wilson, B. W. Spencer, E. G. Erickson, G. Dewey, and R. Hodges, "CAMEL II C6 and C7 Tests: The Primary Control Rod Assembly as a Fue1 Escape Path during the Meltout Phase of an HCDA," Argonne National Laboratory report ANL/RAS 84-8 (February 1984). 